\title{
Observations and model simulations of snow albedo reduction in seasonal snow due to insoluble light-absorbing particles during 2014 Chinese survey
}

\author{
Xin Wang ${ }^{1}$, Wei Pu ${ }^{1}$, Yong Ren ${ }^{1}$, Xuelei Zhang ${ }^{2}$, Xueying Zhang ${ }^{1}$, Jinsen Shi ${ }^{1}$, Hongchun Jin ${ }^{1}$, Mingkai Dai ${ }^{1}$, and \\ Quanliang Chen ${ }^{3}$ \\ ${ }^{1}$ Key Laboratory for Semi-Arid Climate Change of the Ministry of Education, College of Atmospheric Sciences, \\ Lanzhou University, Lanzhou, 730000, China \\ ${ }^{2}$ Key Laboratory of Wetland Ecology and Environment, Northeast Institute of Geography and Agroecology, \\ Chinese Academy of Sciences, Changchun 130102, China \\ ${ }^{3}$ College of Atmospheric Science, Chengdu University of Information Technology, and Plateau Atmospheric and \\ Environment Laboratory of Sichuan Province, Chengdu 610225, China
}

Correspondence to: Xin Wang (wxin@1zu.edu.cn)

Received: 23 July 2016 - Discussion started: 21 September 2016

Revised: 16 January 2017 - Accepted: 16 January 2017 - Published: 14 February 2017

\begin{abstract}
A snow survey was carried out to collect 13 surface snow samples (10 for fresh snow, and 3 for aged snow) and 79 subsurface snow samples in seasonal snow at 13 sites across northeastern China in January 2014. A spectrophotometer combined with chemical analysis was used to quantify snow particulate absorption by insoluble light-absorbing particles (ILAPs, e.g., black carbon, BC; mineral dust, MD; and organic carbon, OC) in snow. Snow albedo was measured using a field spectroradiometer. A new radiative transfer model (Spectral Albedo Model for Dirty Snow, or SAMDS) was then developed to simulate the spectral albedo of snow based on the asymptotic radiative transfer theory. A comparison between SAMDS and an existing model - the Snow, Ice, and Aerosol Radiation (SNICAR) - indicates good agreements in the model-simulated spectral albedos of pure snow. However, the SNICAR model values tended to be slightly lower than those of SAMDS when BC and MD were considered. Given the measured $\mathrm{BC}, \mathrm{MD}$, and $\mathrm{OC}$ mixing ratios of 100-5000, 2000-6000, and 1000-30000 $\mathrm{ng} \mathrm{g}^{-1}$, respectively, in surface snow across northeastern China, the SAMDS model produced a snow albedo in the range of $0.95-0.75$ for fresh snow at $550 \mathrm{~nm}$, with a snow grain optical effective radius $\left(R_{\text {eff }}\right)$ of $100 \mu \mathrm{m}$. The snow albedo reduction due to spherical snow grains assumed to be aged snow is larger than fresh snow such as fractal snow grains
\end{abstract}

and hexagonal plate or column snow grains associated with the increased $\mathrm{BC}$ in snow. For typical $\mathrm{BC}$ mixing ratios of $100 \mathrm{ng} \mathrm{g}^{-1}$ in remote areas and $3000 \mathrm{ng} \mathrm{g}^{-1}$ in heavy industrial areas across northern China, the snow albedo for internal mixing of $\mathrm{BC}$ and snow is lower by 0.005 and 0.036 than that of external mixing for hexagonal plate or column snow grains with $R_{\text {eff }}$ of $100 \mu \mathrm{m}$. These results also show that the simulated snow albedos by both SAMDS and SNICAR agree well with the observed values at low ILAP mixing ratios but tend to be higher than surface observations at high ILAP mixing ratios.

\section{Introduction}

Mineral dust (MD), black carbon (BC), and organic carbon (OC) are three main types of insoluble light-absorbing particles (ILAPs) that play key roles in regional and global climate (Bond et al., 2013; Dang and Hegg, 2014; Hansen et al., 2005; IPCC, 2013; Li et al., 2016; McConnell et al., 2007; $\mathrm{Pu}$ et al., 2015). ILAPs deposited on snow have been found to shorten the snow cover season by decreasing the snow albedo and accelerating snow melt (Brandt et al., 2011; Flanner et al., 2007, 2009; Hadley and Kirchstetter, 2012). The Takla Makan and Gobi deserts and several other deserts are 
well known dust sources across northern China. MD particles produced in these deserts can be lifted up in the atmosphere and transported to the downwelling regions (Che et al., 2011, 2013; Chen et al., 2013; Huang et al., 2008; Jaffe et al., 1999; X. Wang et al., 2008, 2010; Zhang et al., 2003). Carbonaceous aerosols, such as BC and OC, generated from the incomplete combustion of fossil fuels and from biomass burning, are also major anthropogenic pollutants. A mixing ratio of $10 \mathrm{ng} \mathrm{g}^{-1}$ of soot in snow can reduce snow albedo by $1 \%$ (Warren and Wiscombe, 1980). $150 \mathrm{ng} \mathrm{g}^{-1}$ of BC embedded in sea ice can reduce ice albedo by up to $30 \%$ (Light et

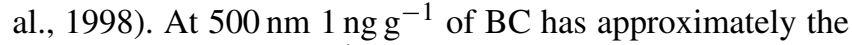
same effect as $50 \mathrm{ng} \mathrm{g}^{-1}$ of dust on the albedo of snow and ice (Warren, 1982). Yasunari et al. (2015) suggested that the existence of snow darkening effect in the earth system associated with ILAPs contributes significantly to enhanced surface warming over continents in northern hemispheric midlatitudes during boreal spring, raising the surface skin temperature by approximately 3-6 K near the snow line. Modeling soot in snow as an "external mixture" (impure particles separated from ice particles), if it is actually located inside the ice grains as an "internal mixture", may underestimate its true effect on albedo reduction by $50 \%$ (Warren and Wiscombe, 1985). Assuming internal rather than external mixing of BC in snow increased BC absorption coefficient by a factor of 2 and gained better agreement with empirical data (Cappa et al., 2012; Hansen and Nazarenko, 2004). Increasing the size of snow grains could decrease snow albedo and amplify the radiative perturbation of BC (Hadley and Kirchstetter, 2012). For a snow grain optical effective radius $\left(R_{\text {eff }}\right)$ of $100 \mu \mathrm{m}$, the albedo reduction caused by $100 \mathrm{ng} \mathrm{g}^{-1}$ of BC is 0.019 for spherical snow grains but only 0.012 for equidimensional nonspherical snow grains (Dang et al., 2016). BC coated with non-absorbing particles absorbs more strongly than the same amount of $\mathrm{BC}$ in an uncoated particle, but the magnitude of this absorption enhancement is yet to be quantified (Fierce et al., 2016). A modeling study suggested that $\mathrm{BC}-$ snow internal mixing increases the albedo forcing by $40-60 \%$ compared with external mixing, and coated BC increases the forcing by 30-50\% compared with uncoated $\mathrm{BC}$ aggregates, whereas Koch snowflakes reduce the forcing by $20-40 \%$ relative to spherical snow grains (He et al., 2014).

Although MD is a less efficient absorber than BC and OC, field campaigns on collecting seasonal snow samples across northern China and the Himalayas have shown high MD loadings (Guan et al., 2015; Kang et al., 2016; Wang et al., 2012, 2013a). In some regions, especially areas with thin and patchy snow cover and mountainous regions, soil dust significantly decreases the snow albedo, exceeding the influence of BC. However, models did not capture these potential large sources of local dust in snowpack and may overestimate BC forcing processes (Painter et al., 2007, 2010, 2012). Recently, several seasonal snow collection campaigns were performed across northern China, the Himalayas, North Amer- ica, Greenland and the Arctic (Cong et al., 2015; Dang and Hegg, 2014; Doherty et al., 2010, 2014; Huang et al., 2011; Xu et al., 2009, 2012; Zhao et al., 2014). However, determining the effects of ILAPs on snow albedo reduction continues to be challenging (Huang et al., 2011; Wang et al., 2013a, 2015; Ye et al., 2012; Zhang et al., 2013a).

To date, only a few studies have compared modeled and observed snow albedo reduction due to ILAPs in snow (Dang et al., 2015; Flanner et al., 2007, 2012; Grenfell et al., 1994; Liou et al., 2014; Warren and Wiscombe, 1980). To gain some in-depth knowledge on this topic, a 2014 snow survey was first performed across northeastern China to analyze light absorption of ILAPs in seasonal snow, and modeling studies were then conducted to compare snow albedo reduction due to various assumptions of internal-external mixing of $\mathrm{BC}$ in snow and different snow grain shapes.

\section{Experimental procedures}

\subsection{Snow field campaign in January 2014}

There was less snowfall in January 2014 than in previous years (e.g., 2010), and thus only 92 snow samples (13 surface snow including 10 fresh and 3 aged ones, and 79 subsurface snow samples) at 13 sites were collected during this snow survey. The snow sampling sites in this study were numbered starting at 90 (see Fig. 1 and Table 1) following the chronological order from Wang et al. (2013a) and Ye et al. (2012). Samples at sites 90-93 were collected from grassland and cropland areas in Inner Mongolia. Sites 9498 and 99-102 were located in the Heilongjiang and Jilin provinces, respectively, which were the most heavily polluted areas in northern China during winter. The snow sampling procedures were similar to those used in the previous survey conducted in 2010 across northern China (Huang et al., 2011). To prevent contamination, the sampling sites were positioned $50 \mathrm{~km}$ from cities and at least $1 \mathrm{~km}$ upwind of approach roads or railways; the only exception was site 101, which was positioned downwind and close to villages. Two vertical profiles of snow samples ("left" and "right") were collected through the whole depth of the snowpack at all the sites to reduce the possible contamination by artificial effects during the sampling process, and the dusty or polluted layers were separately collected during the sampling process. All of the datasets in seasonal snow listed in Table 1 are average values from the two adjacent snow samples through the whole depth of the snowpack. Snow grain sizes $\left(R_{\mathrm{m}}\right)$ were measured by visual inspection on millimeter-gridded sheets viewed through a magnifying glass. The snow samples were kept frozen until the filtration process was initiated. In a temporary lab based in a hotel, we quickly melted the snow samples in a microwave, let them settle for 3-5 min, and then filtered the resulting water samples through a $0.4 \mu \mathrm{m}$ Nuclepore filter to extract particulates. 


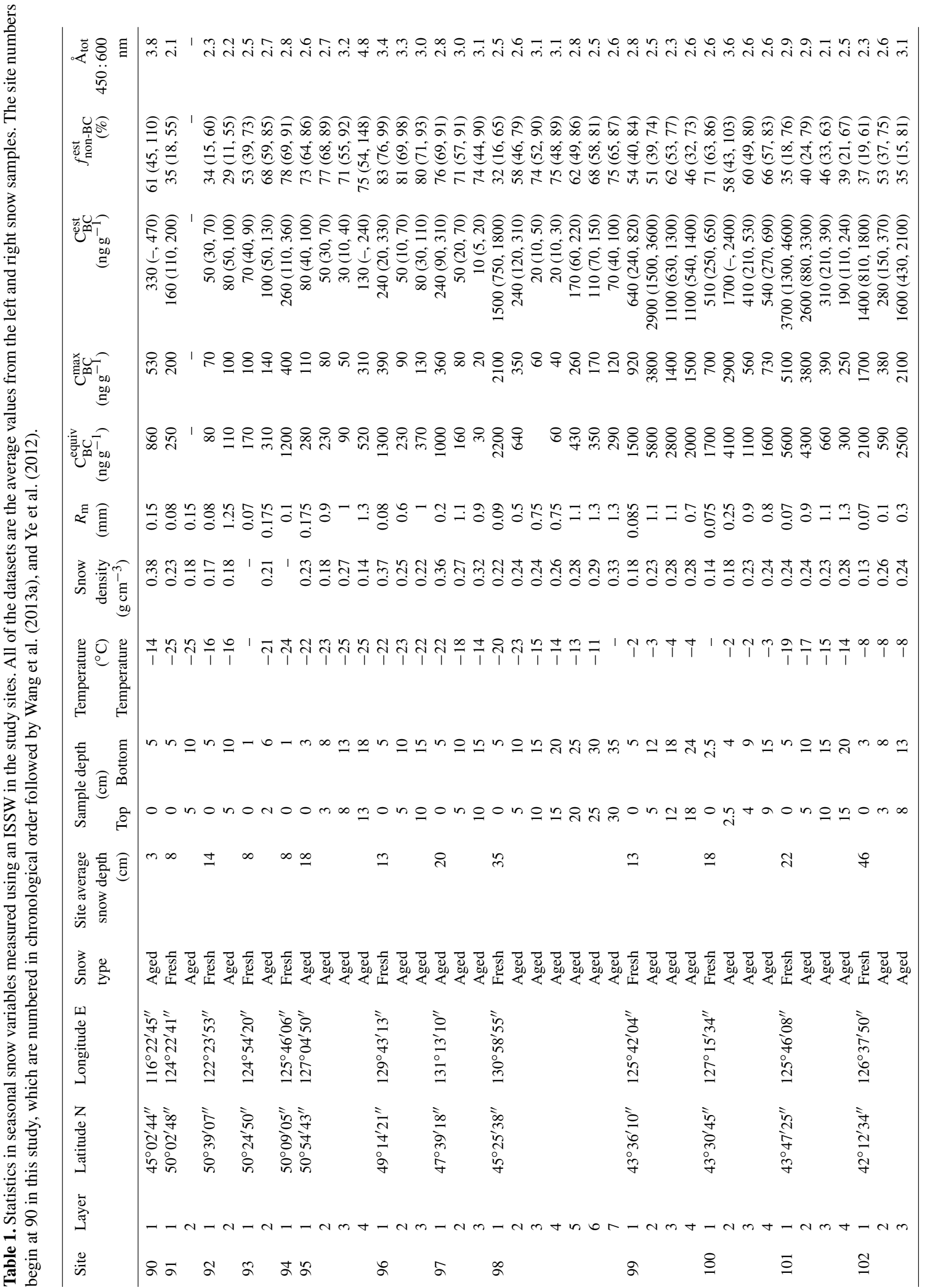




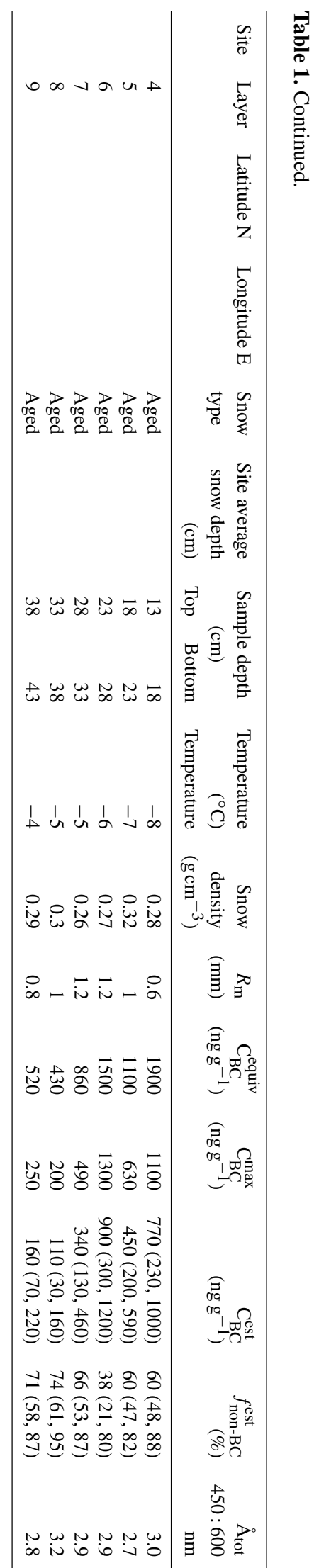

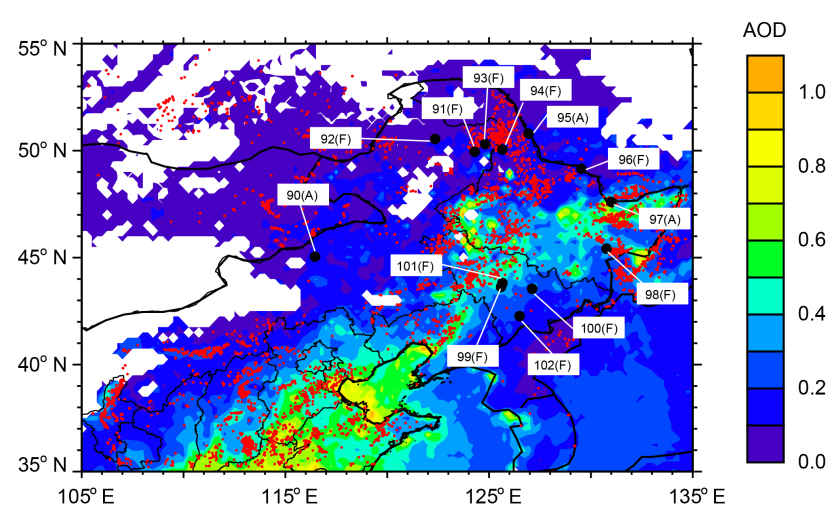

Figure 1. Spatial distribution of the averaged AOD retrieved from Aqua-MODIS over northern China from October 2013 to January 2014. The red dots are MODIS active fire locations, and the black dots are the sampling locations. The site numbers begin at 90 in this study, which are numbered in chronological order followed by Wang et al. (2013a) and Ye et al. (2012). "A" and "F" refer to aged snow and fresh snow, respectively.

\subsection{Chemical speciation}

Major water-soluble ions and trace elements in surface snow samples during this snow survey have already been investigated by Wang et al. (2015). However, the importance of ILAPs in seasonal snow during this survey has not been discussed yet, which will be addressed below. Briefly, major ions $\left(\mathrm{SO}_{4}^{2-}, \mathrm{NO}_{3}^{-}, \mathrm{Cl}^{-}, \mathrm{Na}^{+}, \mathrm{K}^{+}\right.$, and $\left.\mathrm{NH}_{4}^{+}\right)$were analyzed with an ion chromatograph (Dionex, Sunnyvale, CA), and trace elements of $\mathrm{Fe}$ and $\mathrm{Al}$ were measured by inductively coupled plasma mass spectrometry (ICP-MS). These analytical procedures have been described elsewhere (Yesubabu et al., 2014). In this paper, the major ions are used to retrieve the sea salt and bio-smoke potassium $\left(\mathrm{K}_{\text {Biosmoke }}^{+}\right)$. Previous studies have revealed considerable variations in iron $(\mathrm{Fe})$ of $2-5 \%$ in dust (Lafon et al., 2006), although $\mathrm{Al}$ is more stable than Fe in the earth's crust. Hence, we retrieved the mass concentration of MD via the $\mathrm{Al}$ concentration, assuming a fraction of $7 \%$ in MD (Arhami et al., 2006; Lorenz et al., 2006; Zhang et al., 2003). Sea salt was estimated following the method presented in Pio et al. (2007):

$$
\begin{aligned}
\text { Seasalt } & =\mathrm{Na}_{\mathrm{Ss}}^{+}+\mathrm{Cl}^{-}+0.12 \mathrm{Na}_{\mathrm{Ss}}^{+}+0.038 \mathrm{Na}_{\mathrm{Ss}}^{+}+0.038 \mathrm{Na}_{\mathrm{Ss}}^{+} \\
& +0.25 \mathrm{Na}_{\mathrm{Ss}}^{+},
\end{aligned}
$$

where subscript Ss means sea salt sources, and $\mathrm{Na}_{\mathrm{Ss}}$ was calculated using the following formula (Hsu et al., 2009):

$\mathrm{Na}_{\mathrm{Ss}}=\mathrm{Na}_{\text {Total }}-\mathrm{Al} \times(\mathrm{Na} / \mathrm{Al})_{\text {Crust }}$.

Following Hsu et al. (2009), the contribution of $\mathrm{K}_{\text {Biosmoke }}^{+}$ was determined using the following equations: 


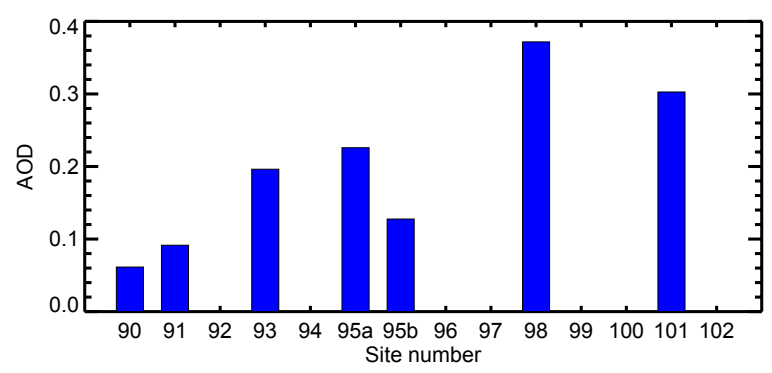

Figure 2. The variation in AOD at $500 \mathrm{~nm}$ at different sites measured using a Microtops $\Pi$ Sunphotometer over northeastern China in January 2014.

$\mathrm{K}_{\text {Biosmoke }}^{+}=\mathrm{K}_{\text {Total }}-\mathrm{K}_{\text {Dust }}-\mathrm{K}_{\mathrm{Ss}}$,

$\mathrm{K}_{\text {Dust }}=\mathrm{Al} \times(\mathrm{K} / \mathrm{Al})_{\text {Crust }}$,

$\mathrm{Na}_{\mathrm{Ss}}=\mathrm{Na}_{\text {Total }}-\mathrm{Al} \times(\mathrm{Na} / \mathrm{Al})_{\text {Crust }}$,

$\mathrm{K}_{\mathrm{Ss}}=\mathrm{NaSs}_{\mathrm{S}} \times 0.038$,

where $\mathrm{K}_{\text {Biosmoke }}^{+}$, $\mathrm{K}_{\text {Dust }}$, and $\mathrm{K}_{\mathrm{Ss}}$ refer to bio-smoke potassium, dust-derived potassium, and sea-salt-derived potassium, respectively. Equations (4), (5), and (6) were derived from Hsu et al. (2009) and Pio et al. (2007).

\subsection{Spectrophotometric analysis}

Recent studies indicated that the light absorption by MD should be more sensitive to the presence of strongly absorbing iron oxides such as hematite and goethite than to other minerals (Alfaro et al., 2004; Sokolik and Toon, 1999). Thus, it is now possible to assess the absorption properties of MD by using iron oxide content (Bond et al., 1999). In this study, the iron in seasonal snow is assumed to originate from MD during this survey, following the procedures performed by Wang et al. (2013a). We measured the mixing ratios of $\mathrm{BC}$ and $\mathrm{OC}$ using an integrating sphere/integrating sandwich spectrophotometer (ISSW), which was first described by Grenfell et al. (2011) and used by Doherty et al. (2010, 2014) and Wang et al. (2013a). The equivalent BC $\left(\mathrm{C}_{\mathrm{BC}}^{\text {equiv }}\right)$, maximum $\mathrm{BC}\left(\mathrm{C}_{\mathrm{BC}}^{\max }\right)$, estimated $\mathrm{BC}\left(\mathrm{C}_{\mathrm{BC}}^{\text {est }}\right)$, fraction of light absorption by non-BC ILAPs $\left(f_{\text {non-BC }}^{\text {est }}\right)$, and absorption Ångström exponent of all ILAPs $\left(\AA_{\text {tot }}\right)$ were described by Doherty et al. (2010). Previous studies have concluded that ILAPs are primarily derived from $\mathrm{BC}, \mathrm{OC}$, and Fe. The mass loadings of $\mathrm{BC}\left(L_{\mathrm{BC}}\right)$ and $\mathrm{OC}\left(L_{\mathrm{OC}}\right)$ were calculated using the following equation:

$\tau_{\mathrm{tot}}(\lambda)=\beta_{\mathrm{BC}}(\lambda) \times L_{\mathrm{BC}}+\beta_{\mathrm{OC}}(\lambda) \times L_{\mathrm{OC}}+\beta_{\mathrm{Fe}}(\lambda) \times L_{\mathrm{Fe}}$.

Here, $\tau_{\text {tot }}(\lambda)$ refers to the measured optical depth. $L_{\mathrm{BC}}$ and $L_{\mathrm{OC}}$ can be determined from this equation assuming that the mass absorption coefficients (MACs) for $\mathrm{BC}, \mathrm{OC}$, and $\mathrm{Fe}$ are $6.3,0.3$, and $0.9 \mathrm{~m}^{2} \mathrm{~g}^{-1}$, respectively, at $550 \mathrm{~nm}$ and that the absorption Ångström exponents ( $\AA$ or AAE) for BC, OC, and $\mathrm{Fe}$ are 1.1, 6, and 3, respectively (e.g., Eqs. 2 and 3 in Wang et al., 2013a).

\subsection{Aerosol optical depth and snow albedo measurements}

The Microtops $\Pi$ Sunphotometer has been widely used to measure aerosol optical depth (AOD) in recent years (More et al., 2013; Porter et al., 2001; Zawadzka et al., 2014) and is recognized as a very useful tool for validating aerosol retrievals from satellite sensors. Ichoku et al. (2002b) and Morys et al. (2001) provided a general description of the Microtops $\Pi$ Sunphotometer's design, calibration, and performance. To better understand the background weather conditions in the local atmosphere during this snow survey, we used a portable and reliable Microtops $\Pi$ Sunphotometer at wavelengths of $340,440,675,870$, and $936 \mathrm{~nm}$ instead of the CE318 sun tracking photometer to measure the surface AOD in this study. AOD measurements were collected in cloudfree conditions between 11:00 and 13:00 (Beijing local time) to prevent the effects of optical distortions due to large solar zenith angles. Then, the Moderate Resolution Imaging Spectroradiometer (MODIS) on the Aqua and Terra satellites was used to retrieve the AOD and fire spot datasets (Kaufman et al., 1997; Zhang et al., 2013b; Zhao et al., 2014). The retrieved MODIS AOD is reliable and accurate when applied to three visible channels over vegetated land and ocean surfaces (Chu et al., 2002; Ichoku et al., 2002a; Remer et al., 2002). Fire locations are based on data provided by the MODIS Fire Information for Resource Management System (FIRMS) system from October 2013 to January 2014. The land-cover types (Figs. 6 and 7) were obtained from the Collection 5.1 MODIS global land-cover type product (MCD12C1) at a $0.05^{\circ}$ spatial resolution and included 17 different surface vegetation types (Friedl et al., 2010; Loveland and Belward, 1997).

Snow albedo plays a key role in energy balance and climate in the cryosphere (e.g., Hadley and Kirchstetter, 2012; Liou et al., 2014; Warren and Wiscombe, 1985). Wright et al. (2014) indicated that the spectral albedo measured using an Analytical Spectral Devices Inc. (ASD) spectroradiometer at $350-2200 \mathrm{~nm}$ is in agreement with albedo measurements at the Baseline Surface Radiation Network (BSRN). Wuttke et al. (2006a) pointed out that the spectroradiometer instrument is considered as the most capable, rapid, and mobile for conducting spectral albedo measurements during short time periods, especially in very cold regions (e.g., in the Arctic). The major advantage is the more extensive wavelength range, and the cosine error is less than $5 \%$ for solar zenith angles below $85^{\circ}$ at a wavelength of $320 \mathrm{~nm}$ (Wuttke et al., 2006a, b). In this study, snow albedo measurements were obtained using a HR-1024 field spectroradiometer (SVC, Spectra Vista Corporation, Poughkeepsie, NY, USA). This instrument has a spectral range of 350-2500 nm with resolutions of 
$3.5 \mathrm{~nm}(350-1000 \mathrm{~nm}), 9.5 \mathrm{~nm}(1000-1850 \mathrm{~nm})$, and $6.5 \mathrm{~nm}$ $(1850-2500 \mathrm{~nm})$. Normally, the relative position of the spectroradiometer is at a distance of $1 \mathrm{~m}$ from the optical element for the active field of view (Carmagnola et al., 2013). A standard "white" reflectance panel with a VIS-SWIR broadband albedo of $0.98\left(P_{\lambda}\right)$ was used to measure the reflectance spectra along with the target. The reflectance spectra of surface snow $\left(R_{\mathrm{S}}\right)$ and the standard panel $\left(R_{\mathrm{p}}\right)$ were measured at least 10 times. Then, the snow albedo $(\alpha)$ was calculated as follows:

$\alpha=\left(R_{\mathrm{S}} / R_{\mathrm{p}}\right) \times P_{\lambda}$.

The nominal field of view (FOV) lens is $8^{\circ}$ to enable the instrument to look at different size targets. In order to receive more direct solar radiation, the direction of the instrument was oriented to the sun horizon angles to measure snow albedo. The small size of the fore optics greatly reduces errors associated with instrument self-shadowing. Even when the area viewed by the fore optic is outside the direct shadow of the instrument, the instrument still blocks some of the illumination (either diffuse skylight or light scattered off surrounding objects) that would normally strike the surface under observation for measuring full-sky irradiance throughout the entire 350-2500 nm wavelengths. Further information on the HR-1024 field spectroradiometer used and on the calibration procedure can be found in Wright et al. (2014). The measured solar zenith angles and the other parameters used to simulate snow albedo in this study have been labeled in Fig. 11.

\subsection{Model simulations}

BC and MD sensitivity effects on the snow albedo simulated by the Snow, Ice, and Aerosol Radiation (SNICAR) model have been validated through recent simulations and field measurements (Flanner et al., 2007, 2009; Qian et al., 2014; Zhao et al., 2014). We used the offline SNICAR model to simulate the reduction in surface snow albedo resulting from ILAP contamination (Flanner et al., 2007), and we compared the results with our spectroradiometer surface measurements. The SNICAR model calculates the snow albedo as the ratio of the upward to downward solar flux at the snow surface. The measured parameters, including the measured snow grain radius $\left(R_{\mathrm{m}}\right)$, snow density, snow thickness, solar zenith angle $\theta$, and mixing ratios of BC and MD, were used to run the SNICAR model under clear sky conditions. The visible and near-infrared albedos of the underlying ground were 0.2 and 0.4, respectively, as derived from MODIS remote sensing. The MAC of BC was assumed to be $7.5 \mathrm{~m}^{2} \mathrm{~g}^{-1}$ at $550 \mathrm{~nm}$.

The Spectral Albedo Model for Dirty Snow (SAMDS) based on asymptotic radiative transfer theory was used for calculating spectral snow albedo as a function of the snow grain radius, the mixing ratios of ILAPs (BC, MD, and OC), and MACs of impurities. A detailed description of asymp- totic analytical radiative transfer theory for SAMDS can be found in Zhang et al. (2017). Briefly, the surface albedo can be calculated using the following asymptotic approximate analytical solution derived from radiative transfer theory (Kokhanovsk and Zege, 2004; Rozenberg, 1962; Zege et al., 1991):

$R_{\mathrm{d}}(\lambda)=\exp \left(-4 S(\lambda) \mu\left(\nu_{0}\right)\right)$.

Here, $R_{\mathrm{d}}(\lambda)$ is the plane albedo, $v_{0}$ is the solar zenith angle, and $\mu\left(v_{0}\right)$ refers to the escape function in radiative transfer theory and is parameterized following Kokhanovsky and Zege (2004):

$\mu\left(v_{0}\right)=\frac{3}{7}\left(1+2 \cos v_{0}\right)$,

where $\lambda$ is the wavelength, $S(\lambda)$ is the similarity parameter, and

$S(\lambda)=\sqrt{\frac{\sigma_{\mathrm{abs}}}{3 \sigma_{\mathrm{ext}}(1-g)}}$.

Here, $\sigma_{\mathrm{abs}}$ and $\sigma_{\mathrm{ext}}$ are the absorption and extinction coefficients, respectively, and $\mathrm{g}$ is the asymmetry parameter (the average cosine of the phase function of the medium).

According to Eqs. (18) and (25) in Kokhanovsky and Zege (2004), the extinction coefficients of particles can be expressed as follows:

$\sigma_{\mathrm{ext}}=\frac{l_{\mathrm{tr}}}{1-g}=\frac{3 \mathrm{C}_{\mathrm{v}}}{2 r_{\mathrm{eff}}}$,

where $l_{\text {tr }}$ is the photon transport path length, $\mathrm{C}_{\mathrm{v}}$ is the volumetric snow particle concentration, and $r_{\mathrm{eff}}$ is the effective grain size, which equals the radius of the volume-to-surface equivalent sphere: $r_{\text {eff }}=\frac{3 \bar{V}}{4 \bar{A}}$, where $\bar{V}$ and $\bar{A}$ are the average volume and cross-sectional (geometric shadow) area of snow grains, respectively.

The absorption coefficient $\sigma_{\mathrm{abs}}$ in Eq. (11) for arbitrarily shaped and weakly absorbing large grains is proportional to the volume concentration (Kokhanovsky and Zege, 2004):

$\sigma_{\mathrm{abs}}=B \cdot \frac{4 \pi k(\lambda)}{\lambda} \cdot \mathrm{C}_{\mathrm{v}}$,

where $k(\lambda)$ is the imaginary component of the complex refractive index for ice, and $B$ is a factor that is only dependent on particle shape. The theory based on the ray-optics approach shows that $g$ in Eq. (11) and $B$ in Eq. (13) are 0.89 and 1.27 for spheres, 0.84 and 1.50 for hexagonal plates or columns, and 0.75 and 1.84 for fractal grains, respectively.

The total absorption coefficient, $\sigma_{\mathrm{abs}}$, can be derived from the absorption by snow, $\sigma_{\mathrm{abs}}^{\text {snow }}$, and the absorption by ILAPs $\left(\sigma_{\mathrm{abs}}^{\mathrm{BC}}, \sigma_{\mathrm{abs}}^{\mathrm{MD}}\right.$, and $\left.\sigma_{\mathrm{abs}}^{\mathrm{OC}}\right)$ :

$\sigma_{\mathrm{abs}}=\sigma_{\mathrm{abs}}^{\mathrm{snow}}+\sigma_{\mathrm{abs}}^{\mathrm{BC}}+\sigma_{\mathrm{abs}}^{\mathrm{MD}}+\sigma_{\mathrm{abs}}^{\mathrm{OC}}$. 
The hemispherical reflectance with a zenith angle $v_{0}$ can be expressed as follows:

$$
\begin{aligned}
& R_{\mathrm{d}}(\lambda)=\exp (-4
\end{aligned}
$$

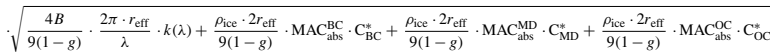

$$
\begin{aligned}
& \left.\cdot \frac{3}{7}\left(1+2 \cos v_{0}\right)\right) \\
& =\exp \left(-\sqrt{94.746 \cdot \frac{r_{\text {eff }}}{\lambda} \cdot k(\lambda)+5.163 \cdot r_{\text {eff }} \cdot\left(\mathrm{MAC}_{\mathrm{abs}}^{\mathrm{BC}} \cdot \mathrm{C}_{\mathrm{BC}}^{*}+\mathrm{MAC}_{\mathrm{abb}}^{\mathrm{MD}} \cdot \mathrm{C}_{\mathrm{MD}}^{*}+\mathrm{MAC}_{\mathrm{abs}}^{\mathrm{OCC}} \cdot \mathrm{C}_{\mathrm{CC}}^{*}\right)}\right. \\
& \left.\cdot\left(1+2 \cos v_{0}\right)\right) \text {, for spherical grains; } \\
& =\exp \left(-4.95 \cdot \sqrt{\frac{\pi \cdot r_{\mathrm{eff}} \cdot\left(k(\lambda)+\alpha \cdot \mathrm{C}_{\mathrm{BC}}^{*}+\beta \cdot \mathrm{C}_{\mathrm{MD}}^{*}+\chi \cdot \mathrm{C}_{\mathrm{OC}}^{*}\right)}{\lambda}}\right. \\
& \left.\cdot\left(1+2 \cos v_{0}\right)\right) \text {, for hexagonal grains; } \\
& =\exp \left(-4.38 \cdot \sqrt{\frac{\pi \cdot r_{\mathrm{eff}} \cdot\left(k(\lambda)+\alpha \cdot \mathrm{C}_{\mathrm{BC}}^{*}+\beta \cdot \mathrm{C}_{\mathrm{MD}}^{*}+\chi \cdot \mathrm{C}_{\mathrm{OC}}^{*}\right)}{\lambda}}\right. \\
& \left.\cdot\left(1+2 \cos v_{0}\right)\right) \text {, for fractal grains. }
\end{aligned}
$$

Previous studies have also shown that the spectral snow albedo is more sensitive to snow grain size and light conditions than BC contamination and snow depths at nearinfrared wavelengths (Warren, 1982). Therefore, the snow grain optical effective radius $\left(R_{\text {eff }}\right)$ was retrieved based on the spectral albedo measured at $\lambda=1.3 \mu \mathrm{m}$, where snow grain size dominates the snow albedo variations and the effects of ILAPs at this wavelength are negligible (Warren and Wiscombe, 1980).

\section{Results}

\subsection{The spatial distribution of AOD}

AOD is a major optical parameter for aerosol particles and a key factor affecting global climate (Holben et al., 1991, 2001, 2006; Smith et al., 2014; Srivastava and Bhardwaj, 2014). Most of the snow samples were collected in the afternoon at the Aqua-MODIS (13:30 LT) overpass time in order to compare the local AODs at sampling sites by using a spectroradiometer with the satellite remote sensing. The AOD spatial distribution derived from the Aqua-MODIS satellite over northern China associated with sampling site numbers is shown in Fig. 1 during this snow survey. The average AOD in the studied area ranged from 0.1 to 1.0 and exhibited strong spatial inhomogeneity. The largest AOD values (up to approximately 1.0) retrieved from the MODIS satellite were associated with anthropogenic pollution over northeastern China during the 2014 sampling period. These large values, which exceeded 0.6, were related to local air pollution from industrial areas (Che et al., 2015; P. Wang et al., 2010). In contrast, the MODIS-Aqua results indicate that the smallest AOD values (as low as 0.1 ) at $550 \mathrm{~nm}$ were found over the Gobi desert in Inner Mongolia and were related to strong winter winds. Similar patterns in the retrieved MODIS AOD were found by Zhao et al. (2014) and Zhang et al. (2013b). Although previous studies have indicated that AOD values across northeastern China are among the highest in East Asia
(Ax et al., 1970; Bi et al., 2014; Che et al., 2009; Routray et al., 2013; Wang et al., 2013b; Xia et al., 2005, 2007), field experiments of aerosol optical properties across northeastern China were limited. Compared with the retrieved AOD by remote sensing, the surface measurements of AOD were also conducted during this snow survey (Fig. 2). Generally, the measured AOD gradually increased from inner Mongolian regions to the industrial areas across northeastern China. In Inner Mongolia, the average AOD was less than 0.25 for sites 90 to 93 under clear sky conditions. We found a large discrepancy of $40-50 \%$ in the same area within the $1 \mathrm{~h}$ measurements collected from sites 95a and 95b, which could be possibly correlated with regional biomass burning. However, AOD exceeded 0.3 at sites 98 and 101, which were significantly influenced by anthropogenic air pollution from industrial areas across northern China. MODIS active fires were often spatially distributed over northeastern China and mainly resulted from human activities during cold seasons.

\subsection{Contributions to light absorption by ILAPs}

The aged surface snow samples were collected at three sites and fresh surface snow samples were collected at the other sites during this snow survey conducted in January 2014. $\mathrm{C}_{\mathrm{BC}}^{\text {est }}, \mathrm{C}_{\mathrm{BC}}^{\max }, \mathrm{C}_{\mathrm{BC}}^{\text {equiv }}, \mathrm{f}_{\text {non-BC }}^{\text {est }}, \AA_{\text {tot }}$, and snow parameters, such as snow depth, snow density, measured snow grain radius $\left(R_{\mathrm{m}}\right)$, and snow temperature, are given in Table 1 and Fig. 3 for each snow layer following Wang et al. (2013a). In Inner Mongolia, the snow cover was thin and patchy. The average snow depth at sites 90,91, 93, and 94 was less than $10 \mathrm{~cm}$, which was significantly smaller than those (13 to $20 \mathrm{~cm}$ ) at sites 95-97 near the northern border of China. The snow samples were collected from drifted snow in Inner Mongolia, and the mass loadings of ILAPs in seasonal snow are mainly due to blowing soil dust. Therefore, the vertical profiles of snow samples mixed with blowing soil from these sites are insufficient to represent the seasonal evolution of wet and dry deposition to snow (Wang et al., 2013a). However, the light absorption of ILAPs is still dominated by OC in these regions, which has been illustrated in the following section. The maximum snow depth was found to be $46 \mathrm{~cm}$ at site 102 inside a forest near the Changbai Shan. Snow depth varied from 13 to $46 \mathrm{~cm}$ at sites 98 to 102 with an average of $27 \mathrm{~cm} . R_{\mathrm{m}}$ of the snow samples varied considerably from 0.07 to $1.3 \mathrm{~mm}$. $R_{\mathrm{m}}$ increased with the snow depth from the surface to the bottom, larger than recorded in previous studies because of snow melting by solar radiation and the ILAPs (Hadley and Kirchstetter, 2012; Motoyoshi et al., 2005; Painter et al., 2013; Pedersen et al., 2015). The snow density exhibited little geographical variation across northern China at 0.13 to $0.38 \mathrm{~g} \mathrm{~cm}^{-3}$. High snow densities resulted from melting or snow aging. Similar snow densities have been found in the Xinjiang region in northern China (Ye et al., 2012). At site 90 , we only collected one layer of snow samples from central Inner Mongolia, and $\mathrm{C}_{\mathrm{BC}}^{\text {est }}$ was $330 \mathrm{ng} \mathrm{g}^{-1}$ for aged snow. 


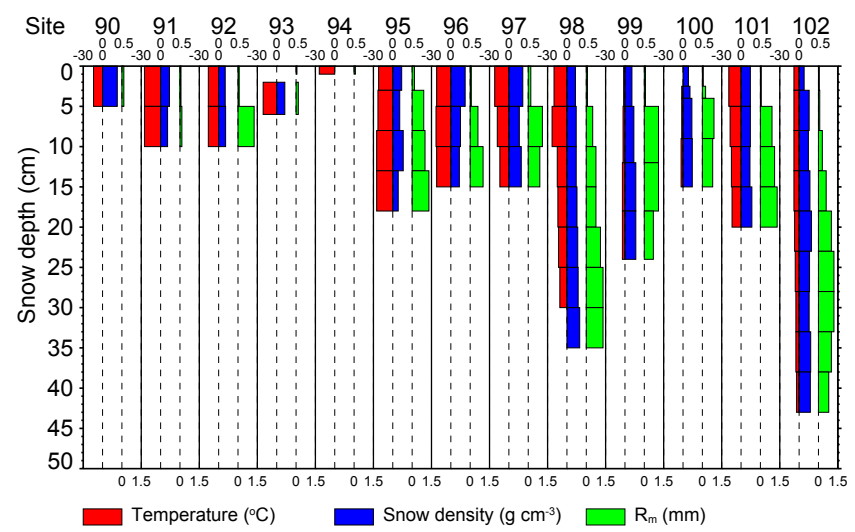

Figure 3. Vertical temperature, snow density, and measured snow grain radius $\left(R_{\mathrm{m}}\right)$ profiles at each site during the 2014 Chinese snow survey.

Along the northern Chinese border at sites $91-95, C_{B C}^{\text {est }}$ in the cleanest snow ranged from 30 to $260 \mathrm{ng} \mathrm{g}^{-1}$, with only a few values exceeding $200 \mathrm{ng} \mathrm{g}^{-1}$. The $f_{\text {non-BC }}^{\text {est }}$ value varied remarkably from 29 to $78 \%$, although $\mathrm{BC}$ was still a major absorber in this region. Heavily polluted sites were located in industrial regions across northeastern China (sites 99-102). The surface snow $C_{B C}^{\text {est }}$ in this region ranged from 510 to $3700 \mathrm{ng} \mathrm{g}^{-1}$, and the highest $\mathrm{C}_{\mathrm{BC}}^{\text {est }}$ in the subsurface layer of the four sites was $2900 \mathrm{ng} \mathrm{g}^{-1}$ (Table 1). In addition, $f_{\text {non-BC }}^{\text {est }}$ was typically $35-74 \%$, indicating significant lightabsorbing contributions by OC and MD from human activity in the heavily polluted areas. $\AA_{\text {tot }}$ ranged from 2.1 to 4.8 . A higher $\AA_{\text {tot }}$ is a good indicator of soil dust, which is primarily driven by the composition of mineral or soil dust. In contrast, a lower $\AA_{\text {tot }}$ of $0.8-1.2$ indicates that ILAPs in the snow are dominated by BC (Bergstrom et al., 2002; Bond et al., 1999).

To better understand the distribution of $\mathrm{C}_{\mathrm{BC}}^{\text {est }}$ in seasonal snow across northern China, the spatial distribution of $\mathrm{C}_{\mathrm{BC}}^{\mathrm{est}}$ in the surface and average snow measured during this snow survey is shown in Fig. 4. The spatial distributions of $\mathrm{C}_{\mathrm{BC}}^{\text {est }}$ in the surface and average snow measured using the ISSW spectrophotometer during the 2014 survey generally ranged from 50 to 3700 and 60 to $1600 \mathrm{ng} \mathrm{g}^{-1}$, with medium values of 260 and $260 \mathrm{ng} \mathrm{g}^{-1}$, respectively. These variations in $C_{B C}^{\text {est }}$ were very similar to those of the previous snow campaign by Wang et al. (2013a); however, they were much higher than those in the Xinjiang region of northwestern China (Ye et al., 2012), along the southern edge of the Tibetan Plateau (Cong et al., 2015), and across North America (Doherty et al., 2014).

Figure 5 compares $C_{\mathrm{BC}}^{\text {est }}$ values measured via the ISSW method with the calculations during 2010 (Wang et al., 2013a) and 2014 snow surveys. The two results agreed very well $\left(R^{2}=0.99\right)$, indicating that Eq. (7) worked well for this measurement, and the $\mathrm{C}_{\mathrm{BC}}^{\mathrm{est}}$ measured via the ISSW method was reliable. To compare with the mixing ratio of OC cal-
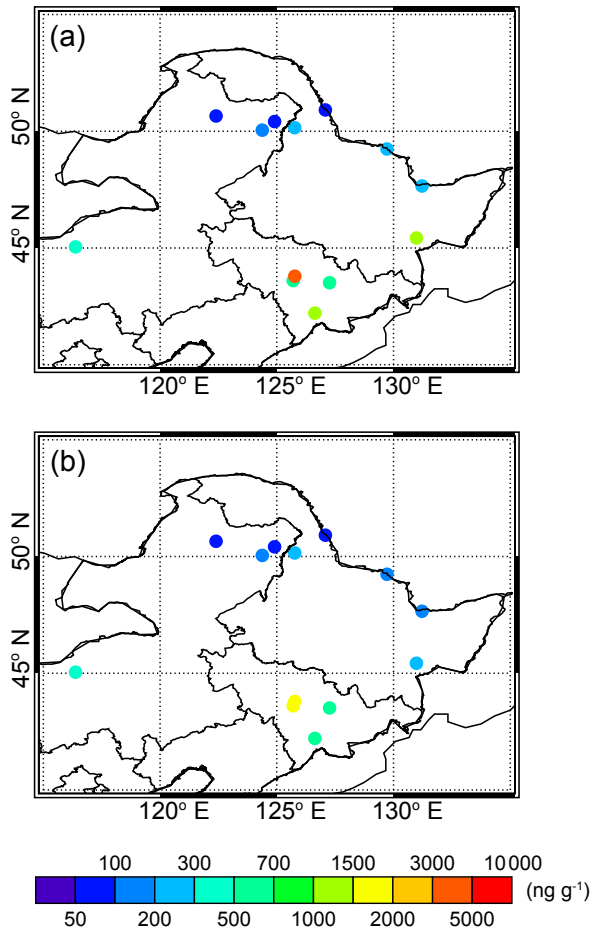

Figure 4. The spatial distribution of $\mathrm{C}_{\mathrm{BC}}^{\mathrm{est}}$ in the (a) surface and (b) average snow in 2014 across northeastern China.

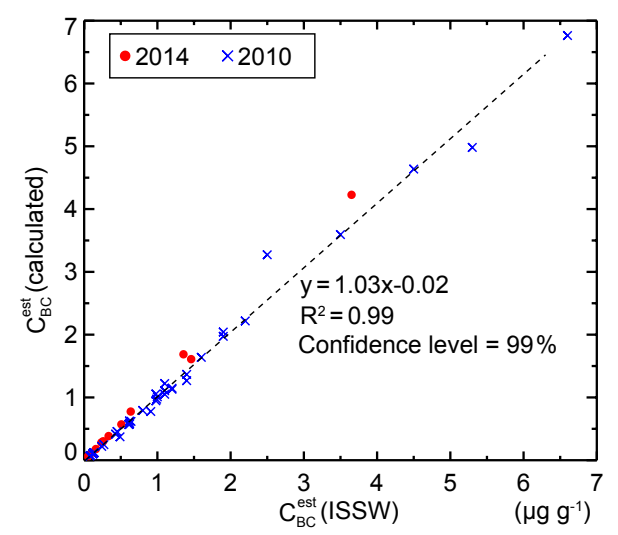

Figure 5. Comparisons between the calculated and optically measured $C_{B C}^{\text {est }}$ in surface snow during the 2010 and 2014 snow surveys. The datasets of measured $C_{B C}^{\text {est }}$ in 2010 from sites 3-40 were reprinted from Wang et al. (2013a).

culated from Eq. (7), we used the calculated $\mathrm{C}_{\mathrm{BC}}^{\text {est }}$ listed in Figs. 6-7 and Table 2 in the following sections.

In Fig. 6, the sampling areas were located in grasslands, croplands, and urban and built-up regions across northern China that were likely influenced by human activity (Huang et al., 2015). According to Table 2 and Fig. 6, the $\mathrm{NH}_{4}^{+}$concentrations emitted from agricultural sources at all sites accounted for less than $2.8 \%$ because the sites were positioned $50 \mathrm{~km}$ from cities. However, large fractions of both $\mathrm{SO}_{4}^{2-}$ 


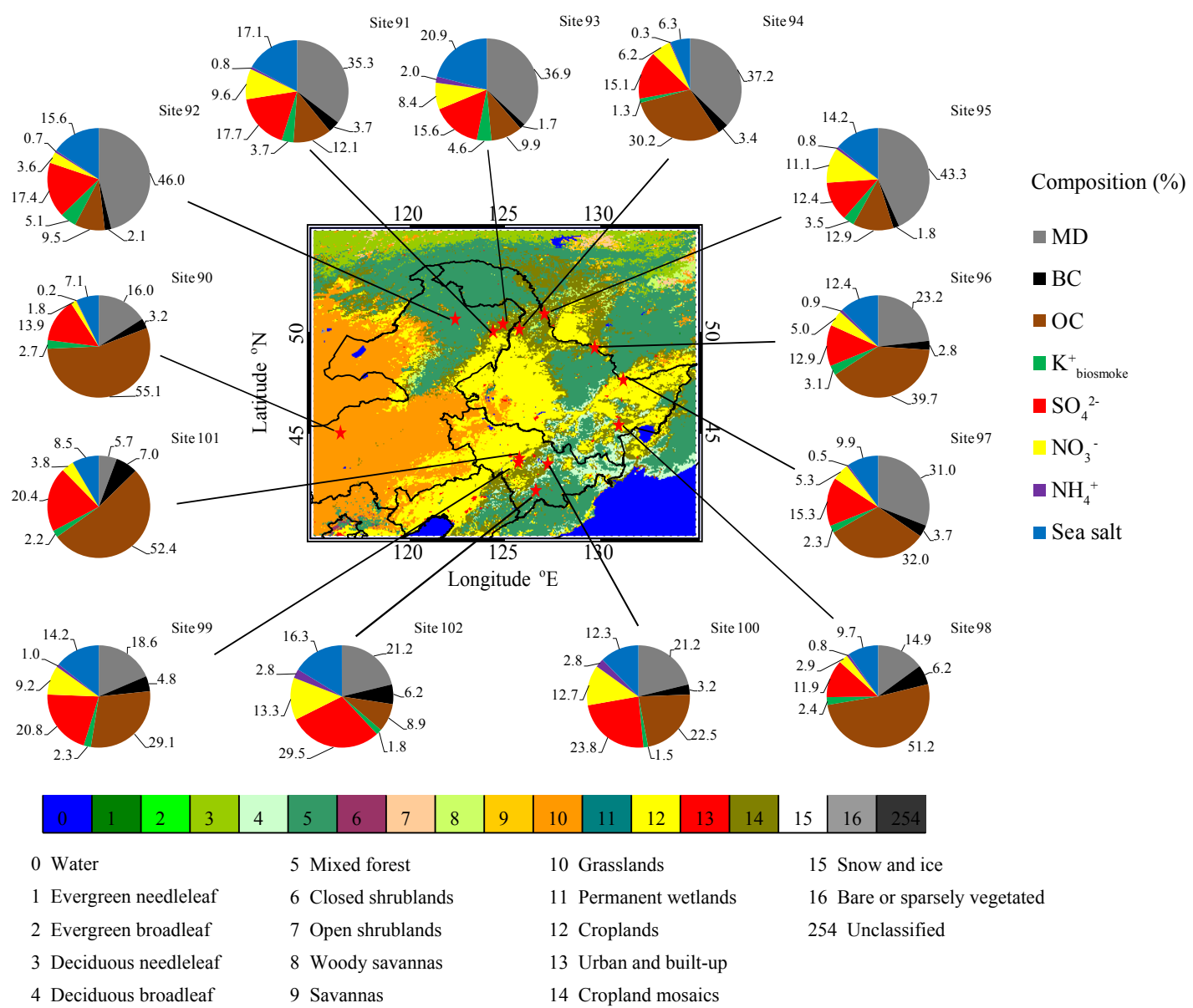

Figure 6. The major components include $\mathrm{MD}, \mathrm{BC}, \mathrm{OC}, \mathrm{K}_{\mathrm{Biosmoke}}^{+}$, secondary ions $\left(\mathrm{SO}_{4}^{2-}, \mathrm{NO}_{3}^{-}\right.$, and $\left.\mathrm{NH}_{4}^{+}\right)$, and sea salt in the surface snow samples collected in January 2014. The distribution of 17 different surface vegetation types retrieved from MODIS global land cover type product $(\mathrm{MCD} 12 \mathrm{C} 1)$ with 0.05 spatial resolution was used in this study. The datasets of $\mathrm{SO}_{4}^{2-}, \mathrm{NO}_{3}^{-}$, and $\mathrm{NH}_{4}^{+}$were reprinted from Wang et al. (2015).

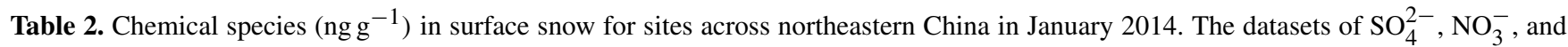
$\mathrm{NH}_{4}^{+}$were reprinted from Wang et al. (2015).

\begin{tabular}{lrrrrrrrr}
\hline Site & $\mathrm{MD}$ & $\mathrm{BC}$ & $\mathrm{OC}$ & $\mathrm{K}_{\text {biosmoke }}^{+}$ & $\mathrm{SO}_{4}^{2-}$ & $\mathrm{NO}_{3}^{-}$ & $\mathrm{NH}_{4}^{+}$ & Sea salt \\
\hline 90 & 1900 & 380 & 6700 & 327 & 1685 & 213 & 22 & 868 \\
91 & 1700 & 180 & 590 & 179 & 853 & 465 & 36 & 827 \\
92 & 1300 & 60 & 280 & 150 & 511 & 105 & 19 & 456 \\
93 & 1700 & 80 & 450 & 213 & 718 & 387 & 90 & 960 \\
94 & 3300 & 300 & 2700 & 118 & 1335 & 550 & 28 & 554 \\
95 & 2000 & 90 & 600 & 164 & 587 & 523 & 39 & 669 \\
96 & 2300 & 280 & 3900 & 309 & 1285 & 493 & 91 & 1227 \\
97 & 2400 & 280 & 2400 & 173 & 1163 & 407 & 38 & 753 \\
98 & 3900 & 1600 & 13300 & 633 & 3096 & 747 & 195 & 2516 \\
99 & 3000 & 770 & 4700 & 372 & 3379 & 1492 & 155 & 2310 \\
100 & 3800 & 570 & 4000 & 260 & 4237 & 2258 & 487 & 2195 \\
101 & 3500 & 4200 & 32000 & 1337 & 12382 & 2364 & - & 5131 \\
102 & 5800 & 1700 & 2400 & 488 & 8034 & 3631 & 769 & 4420 \\
\hline
\end{tabular}




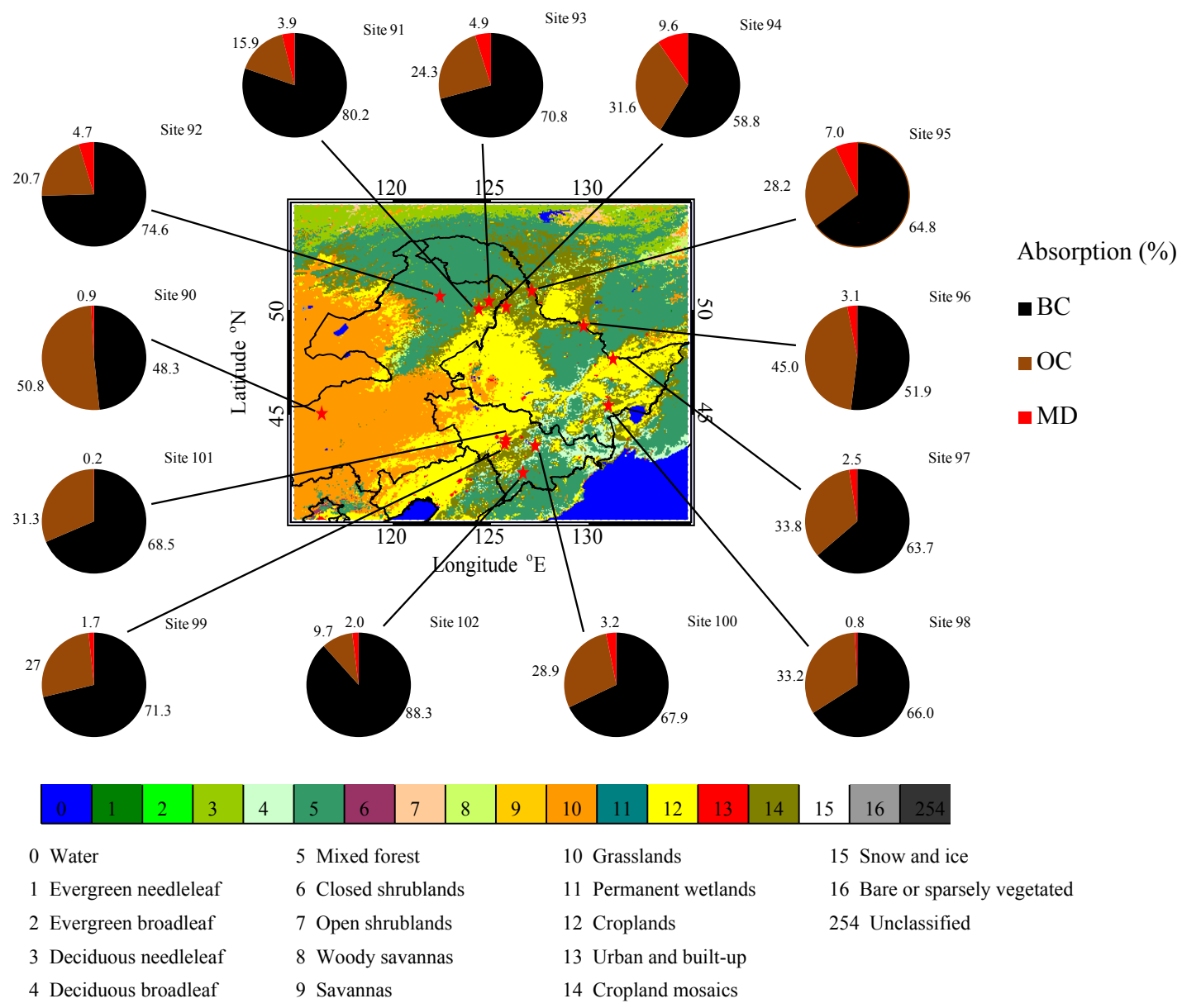

Figure 7. The light absorption of ILAPs in surface snow in January 2014. The distribution of 17 different surface vegetation types retrieved from MODIS global land cover type product (MCD12C1) with 0.05 spatial resolution were used in this study.

and $\mathrm{NO}_{3}^{-}$were observed, varying from 14.8 to $42.8 \%$ at all sites, with the highest fraction of $24.2-42.8 \%$ found in industrial areas. These results show that $\mathrm{SO}_{4}^{2-}$ and $\mathrm{NO}_{3}^{-}$made the greatest contributions to the total chemical concentration in the surface snow as a result of significant anthropogenic emissions of fossil-fuel combustion in heavy industrial areas. More specifically, the largest MD contribution ranged from 35.3 to $46 \%$ at sites 91 to 95 due to strong winds during winter, while the MD fractions were only 5.7 to $31 \%$ at the other sites. Fractions of $\mathrm{BC}$ and $\mathrm{OC}$ were similar to those above, showing that biomass burning was a major source during winter in the sampling region. Zhang et al. (2013b) showed that $\mathrm{OC}$ and $\mathrm{BC}$ fractions vary more widely in the winter than other seasons due to industrial activity in China. Sulfate peaks were found in summer $(15.4 \%)$, whereas nitrate peaks were observed in spring $(11.1 \%)$. $\mathrm{K}_{\text {Biosmoke }}^{+}$was found to be a good tracer of biomass burning, ranging from 1.3 to $5.1 \%$ along the northern Chinese border compared to lower values found at lower latitudes (1.5-2.3\%), and it exhibited much higher contributions in Inner Mongolia and along the northern Chinese border due to increased emissions from cooking, open fires, and agricultural activities. The fraction of sea salt was found to range from 6.3 to $20.9 \%$. Wang et al. (2015) showed that higher $\mathrm{Cl}^{-} / \mathrm{Na}^{+}$ratios in seasonal snow found in the 2014 Chinese survey were 1-2 times greater than those of seawater, implying that they constituted a significant source of anthropogenic $\mathrm{Cl}^{-}$.

Light absorption by ILAPs can be determined from ISSW measurements combined with chemical analysis of $\mathrm{Fe}$ concentration, assuming that the light absorption of dust is dominated by $\mathrm{Fe}$ (Wang et al., 2013a). However, Fe can also originate from industrial emissions, such as the metal and steel industries (Hegg et al., 2010; Ofosu et al., 2012). Doherty et al. (2014) used a similar method to distinguish contributions of ILAPs in snow in central North America. Although heavy MD loading was observed in the 2014 snow survey, the fraction of light absorption due to MD (assumed to exist as goethite) was generally less than $10 \%$ across northeastern China (Fig. 7), which was much smaller than that observed in the Qilian Shan (e.g., Fig. 11 of Wang et al., 2013a). Here, 


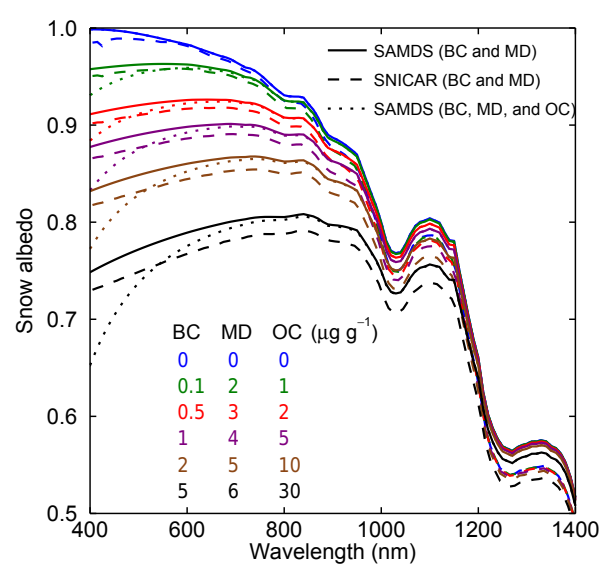

Figure 8. Spectral albedo of snow with different contaminants for a $60^{\circ}$ solar zenith angle and a $100 \mu \mathrm{m} R_{\text {eff. Solid and dashed lines }}$ show the SAMDS and SNICAR model predictions for BC and MD. Dotted lines show the SAMDS model predictions for all ILAPs, including $\mathrm{BC}, \mathrm{MD}$, and $\mathrm{OC}$.

light absorption was mainly dominated by $\mathrm{BC}$ and $\mathrm{OC}$ in snow in January 2014. By contrast, the fraction of light absorption due to $\mathrm{BC}$ varied from 48.3 to $88.3 \%$ at all sites, with only one site dominated by OC (site 90 in central Inner Mongolia). Compared to the light absorption patterns in the Qilian Shan, MD played a less significant role in particulate light absorption in snow across the northeastern Chinese sampling areas.

\subsection{Simulations of snow albedo}

Snow albedo reduction due to $\mathrm{BC}$ has been examined in previous studies (Brandt et al., 2011; Hadley and Kirchstetter, 2012; Yasunari et al., 2010). Here, a new radiative transfer model (SAMDS) based on the asymptotic radiative transfer theory is developed to assess the effects of various factors on snow albedo, including ILAPs in snow, the snow grain shapes, and the internal-external mixing of BC and snow. The snow albedos derived from the SNICAR and SAMDS models are presented in Fig. 8. We ran the models at a solar zenith angle $\theta$ of $60^{\circ}$, which is comparable with our experimental method for measuring snow albedo across northeastern China. The BC MAC used in the two models was $7.5 \mathrm{~m}^{2} \mathrm{~g}^{-1}$ at $550 \mathrm{~nm}$, which was assumed in the most recent climate assessment and is appropriate for freshly emitted BC (Bond and Bergstrom, 2006; Bond et al., 2013; Warren, 1982). Mixing ratios of $\mathrm{BC}, \mathrm{MD}$, and $\mathrm{OC}$ were chosen to vary in the following ranges: $0.1-5,2-6$, and $1-30 \mu \mathrm{g} \mathrm{g}^{-1}$, respectively, encompassing the values measured in snow surfaces across northeastern China in this and previous studies (Doherty et al., 2010, 2014; Wang et al., 2013a, 2014; Warren and Wiscombe, 1980; Ye et al., 2012). Results showed that the albedo of fresh snow at $550 \mathrm{~nm}$ with $R_{\text {eff }}$ of $100 \mu \mathrm{m}$ simulated by SAMDS is generally in the range of $0.95-0.75$ for
ILAP-contaminated snow across northeastern China (Fig. 8). The spectral albedos of pure snow derived from the SNICAR (dashed lines) and SAMDS (solid lines) models agree well. However, there is a slight tendency for the SNICAR model values to become lower than SAMDS model values when BC and MD are considered. The 1-3\% deviation between the SNICAR- and SAMDS-modeled snow albedos at $550 \mathrm{~nm}$ for BC mixing ratios of $1-5 \mu \mathrm{g} \mathrm{g}^{-1}$ indicates that albedo reduction by ILAPs in the SNICAR model was greater than in the SAMDS model. This deviation is in part due to the different parameterization of snow grain shapes, mixing states of snow and $\mathrm{BC}$, and physical-chemical properties of impurities between the two models (Zhang et al., 2017). More notably, snow albedos decreased significantly within the UV-visible wavelength, especially for the higher OC (dotted lines) mixing ratios in Fig. 8. This may be attributed to the fact that $\mathrm{OC}$ strongly absorbs UV-visible radiation and masks BC absorption for high AAE of OC, which decreases remarkably with increasing wavelengths (Warren and Wiscombe, 1980).

As shown in Fig. 9, we also estimated the reduction in the spectrally weighted snow albedo for different $R_{\mathrm{eff}}$ values using the SNICAR and SAMDS models. A larger reduction in snow albedo by both BC- and MD-contaminated snow was found for larger snow grains (Fig. 9a-b). For example, snow albedo reduction attributable to 1,1 , and $10 \mu \mathrm{g} \mathrm{g}^{-1}$ for $\mathrm{BC}, \mathrm{MD}$, and $\mathrm{OC}$, respectively, was 37,41 , and $38 \%$ greater in $200 \mu \mathrm{m}$ snow grains $(0.081,0.0019$, and 0.047$)$ than in $100 \mu \mathrm{m}$ snow grains $(0.059,0.0013$, and 0.034$)$. Both the SNICAR and SAMDS models indicated that the snow albedo is more sensitive to $\mathrm{BC}$, especially at low ILAP mixing ratios. For example, $200 \mathrm{ng} \mathrm{g}^{-1}$ of $\mathrm{BC}$ decreased 0.03 snow albedo at $R_{\text {eff }}$ of $200 \mu \mathrm{m}$, which is much larger than the snow albedo reduction of 0.003 and 0.018 by $2000 \mathrm{ng} \mathrm{g}^{-1}$ of MD and OC at $R_{\text {eff }}$ of $200 \mu \mathrm{m}$. As Hadley and Kirchstetter (2012) noted, compared with pure $55 \mu \mathrm{m}$ snow grains, $300 \mathrm{ng} \mathrm{g}^{-1}$ of BC contamination and growth of $R_{\text {eff }}$ to $110 \mu \mathrm{m}$ caused a net albedo reduction of 0.11 (from 0.82 to 0.71 ) or $61 \%$ more solar energy absorption by snow. The difference in snow albedo reduction between SNICAR and SAMDS models increased with increasing BC mixing ratio or $R_{\text {eff }}$ (Fig. 9a). However, the snow albedo reduction simulated by SNICAR is not always larger than that by SAMDS when the input contaminant is MD instead of BC (Fig. 9b). For example, for $R_{\text {eff }}$ of $100 \mu \mathrm{m}$, the snow albedo reduction from SAMDS is higher than that from SNICAR at MD mixing ratio $<2600 \mathrm{ng} \mathrm{g}^{-1}$ but lower at MD mixing ratio $>2600 \mathrm{ng} \mathrm{g}^{-1}$. The turning point of MD mixing ratio is not constant and depends on the value of $R_{\text {eff }}$. This phenomenon may be a result of the different input optical properties of MD between SAMDS and SNICAR models (Flanner et al., 2007; Zhang et al., 2017). The SAMDS model also considers the effect of OC on snow albedo, while SNICAR model does not. The albedo reduction by OC is non-negligible due to its high loading. As shown, $5000 \mathrm{ng} \mathrm{g}^{-1}$ of OC was found to reduce the snow albedo by $0.016-0.059$ depending on the snow grain size $(50-800 \mu \mathrm{m})$. 

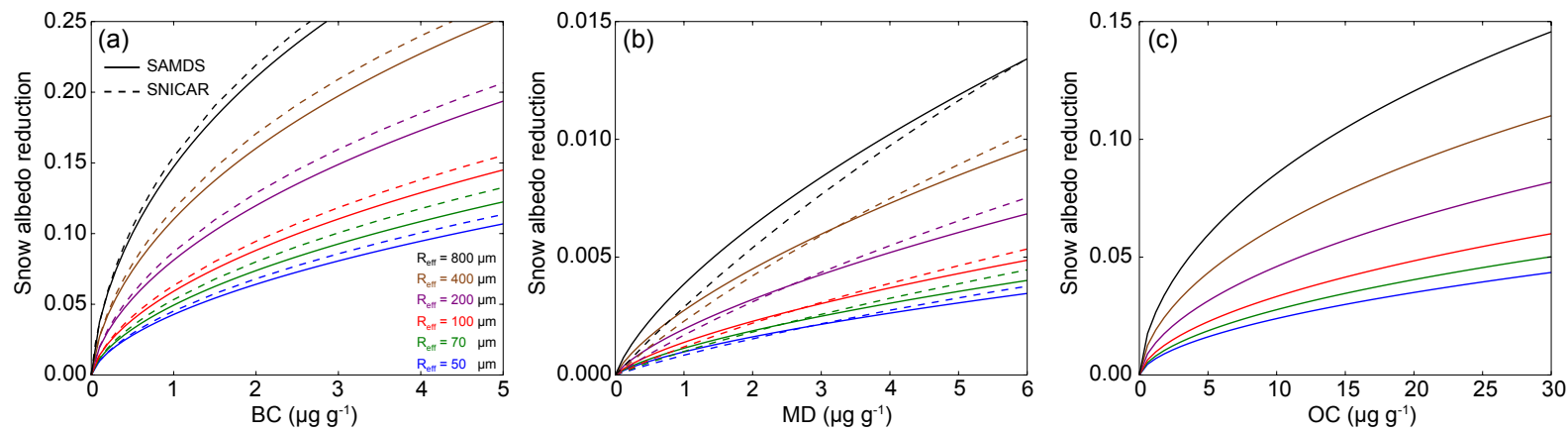

Figure 9. Spectrally weighted snow albedo reduction over the 400-1400 nm solar spectrum attributed to (a) BC, (b) MD, and (c) OC computed as the albedo of pure snow minus the albedo of contaminated snow for a $60^{\circ}$ solar zenith angle. Solid and dashed lines show the SAMDS and SNICAR model predictions. The MAC values of BC, OC, and Fe were assumed to be $7.5,0.3$, and $0.9 \mathrm{~m}^{2} \mathrm{~g}^{-1}$ at $550 \mathrm{~nm}$, respectively, in the SAMDS model.
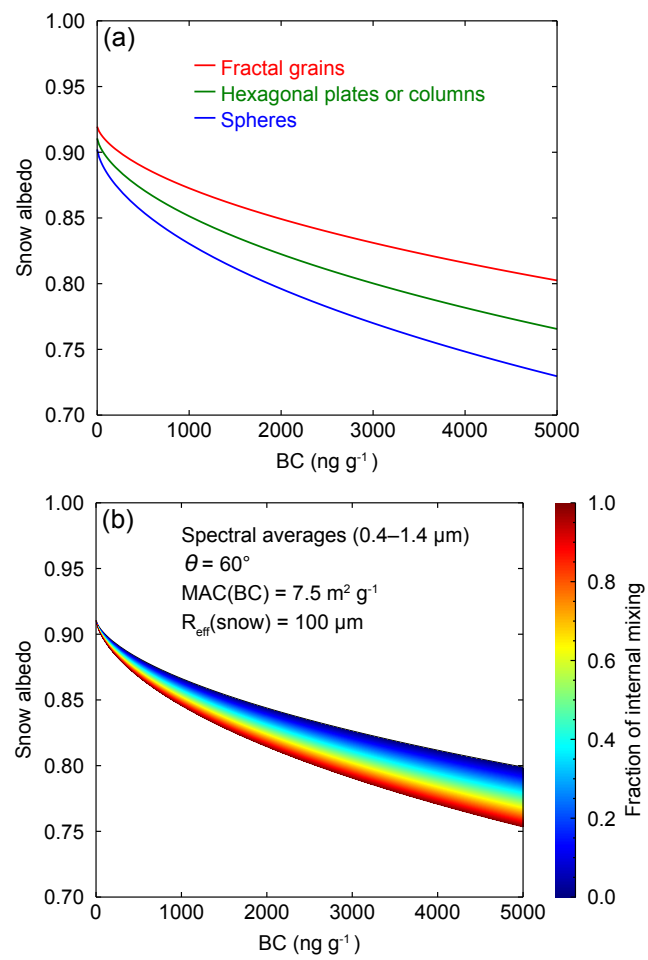

Figure 10. Spectral albedo of snow as a function of BC mixing ratios in snow by using SMDAS model for (a) the irregular morphology of snow grains (fractal grains, hexagonal plates or columns, and spheres), (b) internal-external mixing of BC and hexagonal plate or column snow grains. Also shown are model parameters, including integrate spectral wavelengths $(400-1400 \mathrm{~nm})$, solar zenith angle $(\theta)$, mass absorption coefficient (MAC) of BC, and snow grain optical effective radius ( $\left.R_{\text {eff }}\right)$.

Previous studies have also indicated that the mixing ratio of BC (10-100 $\left.\mathrm{ng} \mathrm{g}^{-1}\right)$ in snow may decrease its albedo by $1-5 \%$ (Hadley and Kirchstetter, 2012; Warren and Wiscombe, 1980). Liou et al. (2011) demonstrated that a small $\mathrm{BC}$ particle on the order of $1 \mu \mathrm{m}$ internally mixed with snow grains could effectively reduce visible snow albedo by as much as 5-10\%. They also found that internal mixing of BC in snow reduces snow albedo more substantially than external mixing, and the snow grain shape plays a critical role in snow albedo calculations through its forward scattering strength by modeling the positions of BC internally mixed with different snow grain types (Liou et al., 2014). Figure 10a illustrates the effect of snow shape (fractal grain, hexagonal plate or column, and sphere) on snow albedo at the spectral wavelengths of $400-1400 \mathrm{~nm}$ with $R_{\text {eff }}$ of $100 \mu \mathrm{m}$ simulated by the SAMDS model. As shown, the differences in snow albedo caused by three snow shapes are remarkable. The snow albedo for spherical snow grains is higher than that for the other two shapes, which is because the scattering by spherical snow grains is more in the forward direction and less to the sides, resulting in a larger $g$ and a smaller $B$, as discussed in Sect. 2.5. In addition, the snow albedo reduction for aged snow such as spherical snow grains is gradually larger than fresh snow such as fractal snow grains and hexagonal plate or column snow grains with the increased BC in snow. It shows that snow albedo by spherical snow grains is typically lower by $0.017-0.073$ than the fractal snow grains, and by $0.008-0.036$ than the hexagonal plate or column snow grains as a function of $\mathrm{BC}$ mixing ratios $\left(0-5000 \mathrm{ng} \mathrm{g}^{-1}\right)$. Dang et al. (2016) assessed the effects of snow grain shapes on snow albedo using the asymmetry factors $g$ of nonspherical ice crystal developed by Fu (2007). They obtained similar results showing that the albedo reduction caused by $100 \mathrm{ng} \mathrm{g}^{-1}$ of BC for spherical snow grains is larger by 0.007 than nonspherical snow grains with the same area-to-mass ratio for $R_{\text {eff }}$ of $100 \mu \mathrm{m}$. Figure $10 \mathrm{~b}$ shows the spectral albedo of snow for the internal-external mixing of BC and snow with $R_{\text {eff }}$ of $100 \mu \mathrm{m}$ for a solar zenith angle $\theta$ of $60^{\circ}$ as a function of $\mathrm{BC}$ mixing ratio. For a given shape (hexagonal plates or columns), we found that snow albedo as a function of $\mathrm{BC}$ mixing ratios calculated from this study decreases as the fraction of the internal mixing increases (Fig. 10b). In previous studies, the $\mathrm{BC}$ mixing ratios in seasonal snow were up to 

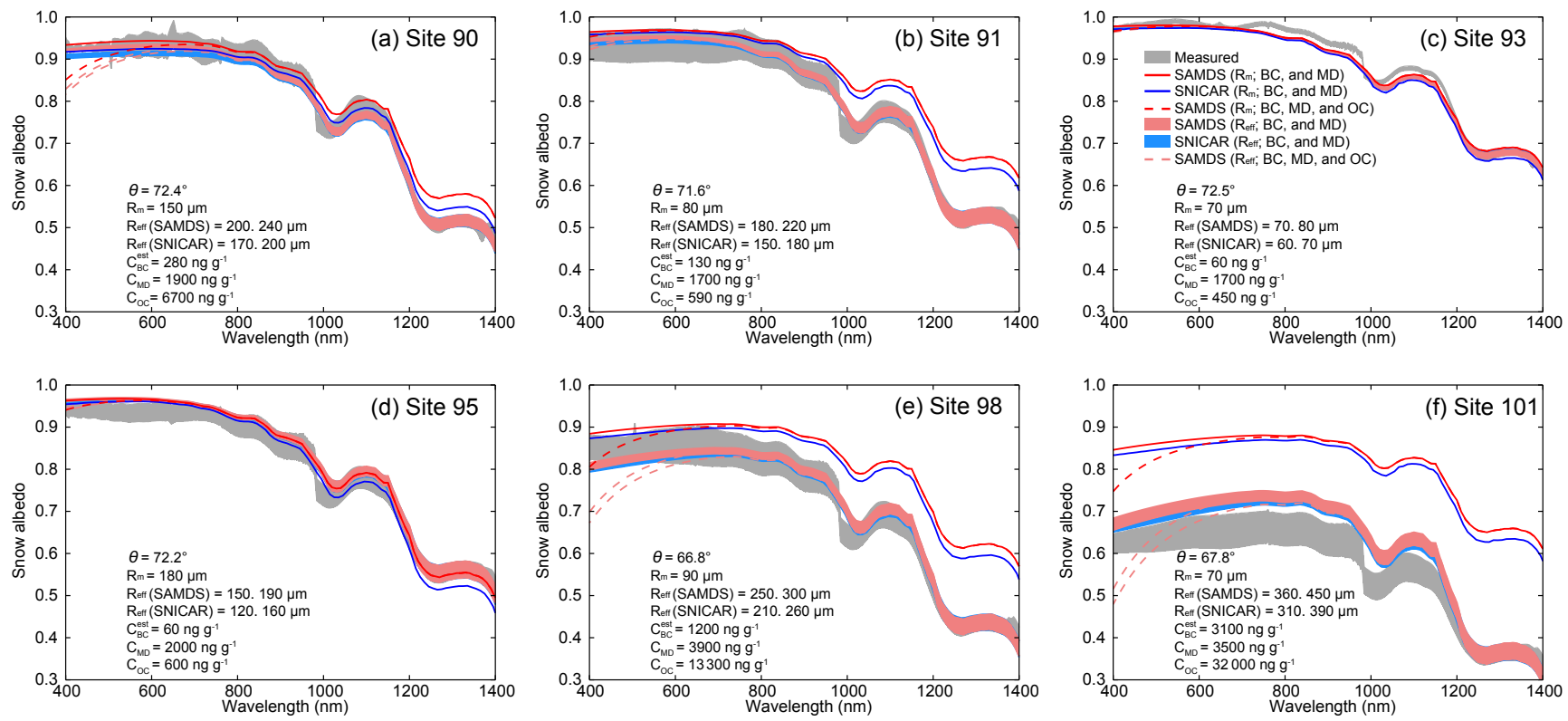

Figure 11. Measured and modeled spectral albedos of snow at sites (a) 90, (b) 91, (c) 93, (d) 95, (e) 98, and (f) 101. Shaded gray bands correspond to measured spectral albedos using spectroradiometer. Solid red and blue lines correspond to spectral albedos simulated by the SAMDS and SNICAR models with measured snow grain radii $\left(R_{\mathrm{m}}\right)$, and shaded light red and blue bands correspond to the albedos with calculated snow grain optical effective radii $\left(R_{\text {eff }}\right)$. Contaminants only include BC and MD in the SAMDS and SNICAR models. In the SNICAR model, the ratio of Fe in dust was assumed to be $2.8 \%$. Dashed red lines are similar to solid red lines, although OC should be added to the list of contaminants in the SAMDS model.

$3000 \mathrm{ng} \mathrm{g}^{-1}$ due to heavy industrial activities across northern China, but the lowest mixing ratios of $\mathrm{BC}$ were found in the remote northeastern area on the border of Siberia, with a median value in surface snow of $100 \mathrm{ng} \mathrm{g}^{-1}$ (Huang et al., 2011; Wang et al., 2013a, 2014; Ye et al., 2012). As a result, snow albedo by internal mixing of $\mathrm{BC}$ and snow is lower than external mixing by up to 0.036 for $3000 \mathrm{ng} \mathrm{g}^{-1} \mathrm{BC}$ in snow in the heavy industrial regions across northeastern China, whereas it is 0.005 for $100 \mathrm{ng} \mathrm{g}^{-1} \mathrm{BC}$ in snow in northern China near the border of Siberia. We indicated that the snow grain shape effect on snow albedo between spherical snow grains and fractal snow grains is relatively larger than the effect of the internal-external mixing of $\mathrm{BC}$ and snow as a function of the BC mixing ratios. However, He et al. (2014) also pointed out that the snow albedo reductions computed by previous models under assorted assumptions vary by a factor of 2 to 5 .

\subsection{Comparison between the observed and modeled snow albedo}

Although the snow albedo reduction due to ILAPs has been investigated by model simulations in recent studies (Brandt et al., 2011; Flanner et al., 2007; Hadley and Kirchstetter, 2012; Liou et al., 2011, 2014; Warren and Wiscombe, 1980), we noted that there were still limited field campaigns on collecting snow samples and measuring ILAPs in seasonal snow associated with the snow albedo reduction at middle latitudes in the Northern Hemisphere (Doherty et al., 2010, 2014; Wang et al., 2013a; Ye et al., 2012). Snow albedo under clear sky conditions was measured at six sites, which was compared to SNICAR and SAMDS model simulations based on two-stream radiative transfer solution of Toon et al. (1989) (Fig. 11). Model input parameters, including $\theta$, $R_{\mathrm{m}}, R_{\mathrm{eff}}$, and the mixing ratios of $\mathrm{BC}\left(\mathrm{C}_{\mathrm{BC}}^{\mathrm{est}}\right), \mathrm{MD}\left(\mathrm{C}_{\mathrm{MD}}\right)$, and $\mathrm{OC}\left(\mathrm{C}_{\mathrm{OC}}\right)$, are also displayed in Fig. 11. The MAC of BC used in the ISSW is $6.3 \mathrm{~m}^{2} \mathrm{~g}^{-1}$ at $550 \mathrm{~nm}$, although a value of 7.5 is used in the SNICAR and SAMDS models. Thus, the value of $\mathrm{C}_{\mathrm{BC}}^{\mathrm{est}}$ was corrected by dividing it by 1.19 (see Fig. 11) when $\mathrm{BC}$ was used as the input parameter to the snow albedo models (Wang et al., 2013a). The snow albedos measured at $550 \mathrm{~nm}$ varied considerably from 0.99 to 0.61 due to different mixing ratios of ILAPs and snow parameters such as snow grain size. The snow albedos predicted by the SNICAR and SAMDS models agreed well at most sites based on the same input parameters. The snow albedos of the SNICAR and SAMDS models retrieved with $R_{\mathrm{m}}$ complemented the surface measurements for lower values of $\mathrm{C}_{\mathrm{BC}}^{\text {est }}, \mathrm{C}_{\mathrm{MD}}$, and $\mathrm{C}_{\mathrm{OC}}$ (Fig. 11a-d). The highest $\mathrm{C}_{\mathrm{BC}}^{\text {est }}$ values were $1500 \mathrm{ng} \mathrm{g}^{-1}$ (corrected value of $1200 \mathrm{ng} \mathrm{g}^{-1}$ ) and $3700 \mathrm{ng} \mathrm{g}^{-1}$ (corrected value of $3100 \mathrm{ng} \mathrm{g}^{-1}$ ) at sites 98 and 101 , respectively, across industrial regions. The OC and MD mixing ratios were as high as 32000 and $3900 \mathrm{ng} \mathrm{g}^{-1}$, respectively, in this region. Therefore, we found a larger difference in snow albedo of up to 0.2 at higher $\mathrm{C}_{\mathrm{BC}}^{\mathrm{est}}, \mathrm{C}_{\mathrm{MD}}$, and 
$\mathrm{C}_{\mathrm{OC}}$ values between the surface measurements and the modeled albedos by both SAMDS and SNICAR models with the input of $R_{\mathrm{m}}$ (solid red and blue lines in Fig. 11e-f). When the snow albedo at the inferred wavelength simulated by using $R_{\mathrm{m}}$ was not accounted for, we also calculated the snow albedos using the SAMDS and SNICAR models with $R_{\text {eff }}$ as shown in Fig. 11 (shaded light red and blue bands). Results showed that compared with the snow albedos simulated using $R_{\mathrm{m}}$, these values were more approximate to the surface measurements, especially at near-infrared wavelengths, although still slightly higher than the surface measurements (shaded gray bands). This may be attributed to the fact that $R_{\text {eff }}$ at these two sampling sites was much larger than $R_{\mathrm{m}}$. We assumed that, for the same snow grains, ILAPs are able to enhance the $R_{\text {eff }}$ in spite of the same $R_{\mathrm{m}}$, which should be verified by future field measurements of snow albedos.

Results shown in Figs. 9 and 11 confirm that BC, OC, and MD are three main types of ILAPs in snow that can reduce spectral snow albedo. The magnitudes of snow albedo reduction due to ILAPs found in our measurements were generally comparable to those produced by the SAMDS and SNICAR models (Flanner et al., 2007; Zhang et al., 2017). When the mixing ratios of ILAPs are not quite high, we indicate that $100-500 \mathrm{ng} \mathrm{g}^{-1}$ of BC can lower the snow albedo by 0.014 0.039 relative to pure snow with a snow grain size of $100 \mu \mathrm{m}$, according to our snow field campaign. Furthermore, MD was found to be a weak absorber due to its lower MD MAC, supporting previous observations made by Warren and Wiscombe (1980). The OC MAC is also lower and comparable to that of the MD. A clear decreasing trend in the surface snow albedo due to the high ambient mixing ratios of OC from Inner Mongolia to northeastern China was found. The radiative transfer model results presented by Zhang et al. (2017) and measurement results of this study show that the spectral albedo of snow reduction due to the increased $\mathrm{OC}$ mixing ratios (above $20 \mu \mathrm{g} \mathrm{g}^{-1}$ ) is larger by a factor of 3 if assuming the snow grain size of 800 compared to $100 \mu \mathrm{m}$.

\section{Conclusions}

High AODs measured using a sunphotometer and remote sensing devices showed continued heavy pollution in industrial regions across northern China. The measured $\mathrm{C}_{\mathrm{BC}}^{\mathrm{est}}$ through the 2014 survey via the ISSW spectrophotometer in surface and average snow were much larger than those of previous snow field campaigns. Light absorption was likely dominated by $\mathrm{BC}$ and $\mathrm{OC}$ in seasonal snow during the entire campaign, as demonstrated with reasonably assumed values of MACs for BC, OC, and Fe.

Model simulation results indicated that the snow albedo for spherical snow grains is typically lower than that for the fractal snow grains and hexagonal plate or column snow grains with $R_{\text {eff }}$ of $100 \mu \mathrm{m}$. The internal mixing of BC and snow absorbs substantially more light than external mixing.
Snow albedos simulated using the SNICAR and SAMDS models using $R_{\mathrm{m}}$ agreed well with the measured ones from the spectroradiometer at low mixing ratios of $\mathrm{BC}, \mathrm{MD}$, and OC, but with large discrepancies for heavy loading of ILAPs in snow. Snow albedo reduction simulated by SMDAS and SNICAR models is significantly higher using $R_{\text {eff }}$ of snow grains than using $R_{\mathrm{m}}$, especially in the case of near-infrared wavelengths. The mixing ratio of OC should be added as an input parameter to the SNICAR model for determining snow albedo.

Future snow survey studies across northern China should be performed to address the large variations in ILAPs in seasonal snow across the region. Additional model simulations and comparisons with measurements are needed to verify $R_{\text {eff }}$ effect under the scenario of high mixing ratios of ILAPs in snow.

\section{Data availability}

All data sets and codes used to produce this study can be obtained by contacting Xin Wang (wxin@lzu.edu.cn). The MODIS data used in this study are available at Aerosol Product, https://modis.gsfc.nasa.gov/data/dataprod/ mod04.php; Active Fire Product, http://earthdata.nasa.gov/ firms; and Land Cover Type Product, https://lpdaac.usgs.gov/ dataset_discovery/modis/modis_products_table/mcd12c1.

Competing interests. The authors declare that they have no conflict of interest.

Acknowledgements. This research was supported by the Foundation for Innovative Research Groups of the National Natural Science Foundation of China (41521004), the National Natural Science Foundation of China under grant 41522505, and the Fundamental Research Funds for the Central Universities (lzujbky-2015-k01, lzujbky-2016-k06 and lzujbky-2015-3). The MODIS data were obtained from the NASA Earth Observing System Data and Information System, Land Processes Distributed Active Archive Center (LP DAAC) at the USGS Earth Resources Observation and Science (EROS) Center.

Edited by: L. Zhang

Reviewed by: two anonymous referees

\section{References}

Alfaro, S. C., Lafon, S., Rajot, J. L., Formenti, P., Gaudichet, A., and Maille, M.: Iron oxides and light absorption by pure desert dust: An experimental study, J. Geophys. Res.-Atmos., 109, D08208, doi:10.1029/2003JD004374, 2004.

Arhami, M., Kuhn, T., Fine, P. M., Delfino, R. J., and Sioutas, C.: Effects of sampling artifacts and operating parameters on 
the performance of a semicontinuous particulate elemental carbon/organic carbon monitor, Environ. Sci. Technol., 40, 945954, 2006.

Ax, W., Malchow, H., Koren, H., and Fischer, H.: Studies on immunological reactions in vitro, Sbornik vedeckych praci Lekarske fakulty Karlovy university v Hradci Kralove, 13, 287292, 1970.

Bergstrom, R. W., Russell, P. B., and Hignett, P.: Wavelength dependence of the absorption of black carbon particles: Predictions and results from the TARFOX experiment and implications for the aerosol single scattering albedo, J. Atmos. Sci., 59, 567-577, 2002

Bi, J. R., Huang, J. P., Hu, Z. Y., Holben, B. N., and Guo, Z. Q.: Investigating the aerosol optical and radiative characteristics of heavy haze episodes in Beijing during January of 2013, J. Geophys. Res.-Atmos., 119, 9884-9900, 2014.

Bond, T. C. and Bergstrom, R. W.: Light absorption by carbonaceous particles: An investigative review, Aerosol Sci. Tech., 40, 27-67, 2006

Bond, T. C., Bussemer, M., Wehner, B., Keller, S., Charlson, R. J., and Heintzenberg, J.: Light absorption by primary particle emissions from a lignite burning plant, Environ. Sci. Technol., 33, 3887-3891, 1999.

Bond, T. C., Doherty, S. J., Fahey, D. W., Forster, P. M., Berntsen, T., DeAngelo, B. J., Flanner, M. G., Ghan, S., Karcher, B., Koch, D., Kinne, S., Kondo, Y., Quinn, P. K., Sarofim, M. C., Schultz, M. G., Schulz, M., Venkataraman, C., Zhang, H., Zhang, S., Bellouin, N., Guttikunda, S. K., Hopke, P. K., Jacobson, M. Z., Kaiser, J. W., Klimont, Z., Lohmann, U., Schwarz, J. P., Shindell, D., Storelvmo, T., Warren, S. G., and Zender, C. S.: Bounding the role of black carbon in the climate system: A scientific assessment, J. Geophys. Res.-Atmos., 118, 5380-5552, 2013.

Brandt, R. E., Warren, S. G., and Clarke, A. D.: A controlled snowmaking experiment testing the relation between black carbon content and reduction of snow albedo, J. Geophys. Res.-Atmos., 116, D08109, doi:10.1029/2010JD015330, 2011.

Cappa, C. D., Onasch, T. B., Massoli, P., Worsnop, D. R., Bates, T. S., Cross, E. S., Davidovits, P., Hakala, J., Hayden, K. L., Jobson, B. T., Kolesar, K. R., Lack, D. A., Lerner, B. M., Li, S. M., Mellon, D., Nuaaman, I., Olfert, J. S., Petaja, T., Quinn, P. K., Song, C., Subramanian, R., Williams, E. J., and Zaveri, R. A.: Radiative Absorption Enhancements Due to the Mixing State of Atmospheric Black Carbon, Science, 337, 1078-1081, 2012.

Carmagnola, C. M., Domine, F., Dumont, M., Wright, P., Strellis, B., Bergin, M., Dibb, J., Picard, G., Libois, Q., Arnaud, L., and Morin, S.: Snow spectral albedo at Summit, Greenland: measurements and numerical simulations based on physical and chemical properties of the snowpack, The Cryosphere, 7, 1139-1160, doi:10.5194/tc-7-1139-2013, 2013.

Che, H. Z., Yang, Z. F., Zhang, X. Y., Zhu, C. Z., Ma, Q. L., Zhou, H. G., and Wang, P.: Study on the aerosol optical properties and their relationship with aerosol chemical compositions over three regional background stations in China, Atmos. Environ., 43, 1093-1099, 2009.

Che, H. Z., Wang, Y. Q., and Sun, J. Y.: Aerosol optical properties at Mt. Waliguan Observatory, China, Atmos. Environ., 45, 60046009, 2011.

Che, H. Z., Wang, Y. Q., Sun, J. Y., Zhang, X. C., Zhang, X. Y., and Guo, J. P.: Variation of Aerosol Optical Properties over the
Taklimakan Desert in China, Aerosol Air Qual. Res., 13, 777 785, 2013.

Che, H. Z., Zhao, H. J., Wu, Y. F., Xia, X. G., Zhu, J., Wang, H., Wang, Y. Q., Sun, J. Y., Yu, J., Zhang, X. Y., and Shi, G. Y.: Analyses of aerosol optical properties and direct radiative forcing over urban and industrial regions in Northeast China, Meteorol. Atmos. Phys., 127, 345-354, 2015.

Chen, S. Y., Huang, J. P., Zhao, C., Qian, Y., Leung, L. R., and Yang, B.: Modeling the transport and radiative forcing of Taklimakan dust over the Tibetan Plateau: A case study in the summer of 2006, J. Geophys. Res.-Atmos., 118, 797-812, 2013.

Chu, D. A., Kaufman, Y. J., Ichoku, C., Remer, L. A., Tanre, D., and Holben, B. N.: Validation of MODIS aerosol optical depth retrieval over land, Geophys. Res. Lett., 29, 1617, doi:10.1029/2001GL013205, 2002.

Cong, Z., Kang, S., Kawamura, K., Liu, B., Wan, X., Wang, Z., Gao, S., and Fu, P.: Carbonaceous aerosols on the south edge of the Tibetan Plateau: concentrations, seasonality and sources, Atmos. Chem. Phys., 15, 1573-1584, doi:10.5194/acp-15-15732015, 2015.

Dang, C. and Hegg, D. A.: Quantifying light absorption by organic carbon in Western North American snow by serial chemical extractions, J. Geophys. Res.-Atmos., 119, 10247-10261, 2014.

Dang, C., Brandt, R. E., and Warren, S. G.: Parameterizations for narrowband and broadband albedo of pure snow and snow containing mineral dust and black carbon, J. Geophys. Res.-Atmos., 120, 5446-5468, 2015.

Dang, C., Fu, Q., and Warren, S. G.: Effect of Snow Grain Shape on Snow Albedo, J. Atmos. Sci., 73, 3573-3583, 2016.

Doherty, S. J., Warren, S. G., Grenfell, T. C., Clarke, A. D., and Brandt, R. E.: Light-absorbing impurities in Arctic snow, Atmos. Chem. Phys., 10, 11647-11680, doi:10.5194/acp-1011647-2010, 2010.

Doherty, S. J., Dang, C., Hegg, D. A., Zhang, R. D., and Warren, S. G.: Black carbon and other light-absorbing particles in snow of central North America, J. Geophys. Res.-Atmos., 119, 1280712831, 2014.

Fierce, L., Bond, T. C., Bauer, S. E., Mena, F., and Riemer, N.: Black carbon absorption at the global scale is affected by particle-scale diversity in composition, Nat. Commun., 7, 12361, doi:10.1038/ncomms12361, 2016.

Flanner, M. G., Zender, C. S., Randerson, J. T., and Rasch, P. J.: Present-day climate forcing and response from black carbon in snow, J. Geophys. Res.-Atmos., 112, D11202, doi:10.1029/2006JD008003, 2007.

Flanner, M. G., Zender, C. S., Hess, P. G., Mahowald, N. M., Painter, T. H., Ramanathan, V., and Rasch, P. J.: Springtime warming and reduced snow cover from carbonaceous particles, Atmos. Chem. Phys., 9, 2481-2497, doi:10.5194/acp-9-24812009, 2009.

Flanner, M. G., Liu, X., Zhou, C., Penner, J. E., and Jiao, C.: Enhanced solar energy absorption by internally-mixed black carbon in snow grains, Atmos. Chem. Phys., 12, 4699-4721, doi:10.5194/acp-12-4699-2012, 2012.

Friedl, M. A., Sulla-Menashe, D., Tan, B., Schneider, A., Ramankutty, N., Sibley, A., and Huang, X. M.: MODIS Collection 5 global land cover: Algorithm refinements and characterization of new datasets, Remote Sens. Environ., 114, 168-182, 2010. 
Fu, Q.: A New Parameterization of an Asymmetry Factor of Cirrus Clouds for Climate Models, J. Atmos. Sci., 64, 4140-4150, 2007. Grenfell, T. C., Warren, S. G., and Mullen, P. C.: Reflection of SolarRadiation by the Antarctic Snow Surface at Ultraviolet, Visible, and near-Infrared Wavelengths, J. Geophys. Res.-Atmos., 99, 18669-18684, 1994.

Grenfell, T. C., Doherty, S. J., Clarke, A. D., and Warren, S. G.: Light absorption from particulate impurities in snow and ice determined by spectrophotometric analysis of filters, Appl. Optics, 50, 2037-2048, 2011.

Guan, X., Huang, J., Guo, R., Yu, H., Lin, P., and Zhang, Y.: Role of radiatively forced temperature changes in enhanced semi-arid warming in the cold season over east Asia, Atmos. Chem. Phys., 15, 13777-13786, doi:10.5194/acp-15-13777-2015, 2015.

Hadley, O. L. and Kirchstetter, T. W.: Black-carbon reduction of snow albedo, Nat. Clim. Change, 2, 437-440, 2012.

Hansen, J. and Nazarenko, L.: Soot climate forcing via snow and ice albedos, P. Natl. Acad. Sci. USA, 101, 423-428, 2004.

Hansen, J., Sato, M., Ruedy, R., Nazarenko, L., Lacis, A., Schmidt, G. A., Russell, G., Aleinov, I., Bauer, M., Bauer, S., Bell, N., Cairns, B., Canuto, V., Chandler, M., Cheng, Y., Del Genio, A., Faluvegi, G., Fleming, E., Friend, A., Hall, T., Jackman, C., Kelley, M., Kiang, N., Koch, D., Lean, J., Lerner, J., Lo, K., Menon, S., Miller, R., Minnis, P., Novakov, T., Oinas, V., Perlwitz, J., Perlwitz, J., Rind, D., Romanou, A., Shindell, D., Stone, P., Sun, S., Tausnev, N., Thresher, D., Wielicki, B., Wong, T., Yao, M., and Zhang, S.: Efficacy of climate forcings, J. Geophys. Res.Atmos., 110, D18104, doi:10.1029/2005JD005776, 2005.

He, C. L., Li, Q. B., Liou, K. N., Takano, Y., Gu, Y., Qi, L., Mao, Y. H., and Leung, L. R.: Black carbon radiative forcing over the Tibetan Plateau, Geophys. Res. Lett., 41, 7806-7813, 2014.

Hegg, D. A., Warren, S. G., Grenfell, T. C., Sarah J Doherty, and Clarke, A. D.: Sources of light-absorbing aerosol in arctic snow and their seasonal variation, Atmos. Chem. Phys., 10, 1092310938, doi:10.5194/acp-10-10923-2010, 2010.

Holben, B. N., Eck, T. F., and Fraser, R. S.: Temporal and Spatial Variability of Aerosol Optical Depth in the Sahel Region in Relation to Vegetation Remote-Sensing, Int. J. Remote Sens., 12, 1147-1163, 1991.

Holben, B. N., Tanre, D., Smirnov, A., Eck, T. F., Slutsker, I., Abuhassan, N., Newcomb, W. W., Schafer, J. S., Chatenet, B., Lavenu, F., Kaufman, Y. J., Castle, J. V., Setzer, A., Markham, B., Clark, D., Frouin, R., Halthore, R., Karneli, A., O’Neill, N. T., Pietras, C., Pinker, R. T., Voss, K., and Zibordi, G.: An emerging ground-based aerosol climatology: Aerosol optical depth from AERONET, J. Geophys. Res.-Atmos., 106, 12067-12097, 2001.

Holben, B. N., Eck, T. F., Slutsker, I., Smirnov, A., Sinyuk, A., Schafer, J., Giles, D., and Dubovik, O.: AERONET's Version 2.0 quality assurance criteria, Remote Sensing of the Atmosphere and Clouds, 6408, 64080Q, doi:10.1117/12.706524, 2006.

Hsu, S. C., Liu, S. C., Huang, Y. T., Chou, C. C. K., Lung, S. C. C., Liu, T. H., Tu, J. Y., and Tsai, F. J.: Long-range southeastward transport of Asian biosmoke pollution: Signature detected by aerosol potassium in Northern Taiwan, J. Geophys. Res.-Atmos., 114, D14301, doi:10.1029/2009JD011725, 2009.

Huang, J. P., Minnis, P., Chen, B., Huang, Z. W., Liu, Z. Y., Zhao, Q. Y., Yi, Y. H., and Ayers, J. K.: Long-range transport and vertical structure of Asian dust from CALIPSO and surface measure- ments during PACDEX, J. Geophys. Res.-Atmos., 113, D23212, doi:10.1029/2008JD010620, 2008.

Huang, J. P., Fu, Q. A., Zhang, W., Wang, X., Zhang, R. D., Ye, H., and Warren, S. G.: Dust and Black Carbon in Seasonal Snow across Northern China, B. Am. Meteorol. Soc., 92, 175-181, 2011.

Huang, J. P., Liu, J. J., Chen, B., and Nasiri, S. L.: Detection of anthropogenic dust using CALIPSO lidar measurements, Atmos. Chem. Phys., 15, 11653-11665, doi:10.5194/acp-1511653-2015, 2015.

Ichoku, C., Chu, D. A., Mattoo, S., Kaufman, Y. J., Remer, L. A., Tanre, D., Slutsker, I., and Holben, B. N.: A spatio-temporal approach for global validation and analysis of MODIS aerosol products, Geophys. Res. Lett., 29, 1616, doi:10.1029/2001GL013206, 2002a.

Ichoku, C., Levy, R., Kaufman, Y. J., Remer, L. A., Li, R. R., Martins, V. J., Holben, B. N., Abuhassan, N., Slutsker, I., Eck, T. F., and Pietras, C.: Analysis of the performance characteristics of the five-channel Microtops II Sun photometer for measuring aerosol optical thickness and precipitable water vapor, J. Geophys. Res.Atmos., 107, 4179, doi:10.1029/2001JD001302, 2002b.

IPCC: Climate Change 2013: The Physical Science Basis. Contribution of Working Group I to the Fifth Assessment Report of the Intergovernmental Panel on Climate Change, edited by: Stocker, T. F., Qin, D., Plattner, G.-K., Tignor, M., Allen, S. K., Boschung, J., Nauels, A., Xia, Y., Bex, V., and Midgley, P. M., Cambridge Univ. Press, Cambridge, United Kingdom and New York, NY, USA, 2013.

Jaffe, D., Anderson, T., Covert, D., Kotchenruther, R., Trost, B., Danielson, J., Simpson, W., Berntsen, T., Karlsdottir, S., Blake, D., Harris, J., Carmichael, G., and Uno, I.: Transport of Asian air pollution to North America, Geophys. Res. Lett., 26, 711-714, 1999.

Kang, L. T., Huang, J. P., Chen, S. Y., and Wang, X.: Long-term trends of dust events over Tibetan Plateau during 1961-2010, Atmos. Environ., 125, 188-198, 2016.

Kaufman, Y. J., Tanre, D., Gordon, H. R., Nakajima, T., Lenoble, J., Frouin, R., Grassl, H., Herman, B. M., King, M. D., and Teillet, P. M.: Passive remote sensing of tropospheric aerosol and atmospheric correction for the aerosol effect, J. Geophys. Res.Atmos., 102, 16815-16830, 1997.

Kokhanovsky, A. A. and Zege, E. P.: Scattering optics of snow, Appl. Optics, 43, 1589-1602, 2004.

Lafon, S., Sokolik, I. N., Rajot, J. L., Caquineau, S., and Gaudichet, A.: Characterization of iron oxides in mineral dust aerosols: Implications for light absorption, J. Geophys. Res.-Atmos., 111, D21207, doi:10.1029/2005JD007016, 2006.

Li, Z., Lau, W. K.-M., Ramanathan, V., Wu, G., Ding, Y., Manoj, M. G., Liu, J., Qian, Y., Li, J., Zhou, T., Fan, J., Rosenfeld, D., Ming, Y., Wang, Y., Huang, J., Wang, B., Xu, X., Lee, S.-S., Cribb, M., Zhang, F., Yang, X., Zhao, C., Takemura, T., Wang, K., Xia, X., Yin, Y., Zhang, H., Guo, J., Zhai, P. M., Sugimoto, N., Babu, S. S., and Brasseur, G. P.: Aerosol and monsoon climate interactions over Asia, Rev. Geophys., 54, 866-929, doi:10.1002/2015RG000500, 2016.

Light, B., Eicken, H., Maykut, G. A., and Grenfell, T. C.: The effect of included particulates on the spectral albedo of sea ice, J. Geophys. Res.-Ocean., 103, 27739-27752, 1998. 
Liou, K. N., Takano, Y., and Yang, P.: Light absorption and scattering by aggregates: Application to black carbon and snow grains, J. Quant. Spectrosc. Ra., 112, 1581-1594, 2011.

Liou, K. N., Takano, Y., He, C., Yang, P., Leung, L. R., Gu, Y., and Lee, W. L.: Stochastic parameterization for light absorption by internally mixed BC/dust in snow grains for application to climate models, J. Geophys. Res.-Atmos., 119, 7616-7632, 2014.

Lorenz, K., Preston, C. M., and Kandeler, E.: Soil organic matter in urban soils: Estimation of elemental carbon by thermal oxidation and characterization of organic matter by solid-state C-13 nuclear magnetic resonance (NMR) spectroscopy, Geoderma, 130, 312-323, 2006.

Loveland, T. R. and Belward, A. S.: The IGBP-DIS global $1 \mathrm{~km}$ land cover data set, DISCover: first results, Int. J. Remote Sens., 18, 3291-3295, 1997.

McConnell, J. R., Edwards, R., Kok, G. L., Flanner, M. G., Zender, C. S., Saltzman, E. S., Banta, J. R., Pasteris, D. R., Carter, M. M., and Kahl, J. D. W.: 20th-century industrial black carbon emissions altered arctic climate forcing, Science, 317, 1381-1384, 2007

More, S., Kumar, P. P., Gupta, P., Devara, P. C. S., and Aher, G. R.: Comparison of Aerosol Products Retrieved from AERONET, MICROTOPS and MODIS over a Tropical Urban City, Pune, India, Aerosol Air Qual. Res., 13, 107-121, 2013.

Morys, M., Mims, F. M., Hagerup, S., Anderson, S. E., Baker, A., Kia, J., and Walkup, T.: Design, calibration, and performance of MICROTOPS II handheld ozone monitor and Sun photometer, J. Geophys. Res.-Atmos., 106, 14573-14582, 2001.

Motoyoshi, H., Aoki, T., Hori, M., Abe, O., and Mochizuki, S.: Possible effect of anthropogenic aerosol deposition on snow albedo reduction at Shinjo, Japan, J. Meteorol. Soc. Jpn., 83A, 137-148, 2005.

Ofosu, F. G., Hopke, P. K., Aboh, I. J. K., and Bamford, S. A.: Characterization of fine particulate sources at Ashaiman in Greater Accra, Ghana, Atmos. Pollut. Res., 3, 301-310, 2012.

Painter, T. H., Barrett, A. P., Landry, C. C., Neff, J. C., Cassidy, M. P., Lawrence, C. R., McBride, K. E., and Farmer, G. L.: Impact of disturbed desert soils on duration of mountain snow cover, Geophys. Res. Lett., 34, L12502, doi:10.1029/2007GL030284, 2007.

Painter, T. H., Deems, J. S., Belnap, J., Hamlet, A. F., Landry, C. C., and Udall, B.: Response of Colorado River runoff to dust radiative forcing in snow, P. Natl. Acad. Sci. USA, 107, 1712517130, 2010.

Painter, T. H., Bryant, A. C., and Skiles, S. M.: Radiative forcing by light absorbing impurities in snow from MODIS surface reflectance data, Geophys. Res. Lett., 39, L17502, doi:10.1029/2012GL052457, 2012.

Painter, T. H., Seidel, F. C., Bryant, A. C., Skiles, S. M., and Rittger, K.: Imaging spectroscopy of albedo and radiative forcing by light-absorbing impurities in mountain snow, J. Geophys. Res.Atmos., 118, 9511-9523, 2013.

Pedersen, C. A., Gallet, J. C., Strom, J., Gerland, S., Hudson, S. R., Forsstrom, S., Isaksson, E., and Berntsen, T. K.: In situ observations of black carbon in snow and the corresponding spectral surface albedo reduction, J. Geophys. Res.-Atmos., 120, 14761489, 2015.

Pio, C. A., Legrand, M., Oliveira, T., Afonso, J., Santos, C., Caseiro, A., Fialho, P., Barata, F., Puxbaum, H., Sanchez-Ochoa, A.,
Kasper-Giebl, A., Gelencser, A., Preunkert, S., and Schock, M.: Climatology of aerosol composition (organic versus inorganic) at nonurban sites on a west-east transect across Europe, J. Geophys. Res.-Atmos., 112, D23S02, doi:10.1029/2006JD008038, 2007.

Porter, J. N., Miller, M., Pietras, C., and Motell, C.: Ship-based sun photometer measurements using Microtops sun photometers, J. Atmos. Ocean. Tech., 18, 765-774, 2001.

Pu, W., Wang, X., Zhang, X. Y., Ren, Y., Shi, J. S., Bi, J. R., and Zhang, B. D.: Size Distribution and Optical Properties of Particulate Matter $\left(\mathrm{PM}_{10}\right)$ and Black Carbon (BC) during Dust Storms and Local Air Pollution Events across a Loess Plateau Site, Aerosol Air Qual. Res., 15, 2212-2224, 2015.

Qian, Y., Wang, H. L., Zhang, R. D., Flanner, M. G., and Rasch, P. J.: A sensitivity study on modeling black carbon in snow and its radiative forcing over the Arctic and Northern China, Environ. Res. Lett., 9, 064001, doi:10.1088/1748-9326/9/6/064001, 2014.

Remer, L. A., Tanre, D., Kaufman, Y. J., Ichoku, C., Mattoo, S., Levy, R., Chu, D. A., Holben, B., Dubovik, O., Smirnov, A., Martins, J. V., Li, R. R., and Ahmad, Z.: Validation of MODIS aerosol retrieval over ocean, Geophys. Res. Lett., 29, 1618, doi:10.1029/2001GL013204, 2002.

Routray, A., Mohanty, U. C., Osuri, K. K., and Prasad, S. K.: Improvement of Monsoon Depressions Forecast with Assimilation of Indian DWR Data Using WRF-3DVAR Analysis System, Pure Appl. Geophys., 170, 2329-2350, 2013.

Rozenberg, G.: Optical characteristics of thick weakly absorbing scattering layers, Dokl. Akad. Nauk SSSR, 145, 775-777, 1962.

Smith, T. M., Gao, J. D., Calhoun, K. M., Stensrud, D. J., Manross, K. L., Ortega, K. L., Fu, C. H., Kingfield, D. M., Elmore, K. L., Lakshmanan, V., and Riedel, C.: Examination of a Real-Time 3DVAR Analysis System in the Hazardous Weather Testbed, Weather Forecast., 29, 63-77, 2014.

Sokolik, I. N. and Toon, O. B.: Incorporation of mineralogical composition into models of the radiative properties of mineral aerosol from UV to IR wavelengths, J. Geophys. Res.-Atmos., 104, 9423-9444, 1999.

Srivastava, K. and Bhardwaj, R.: Analysis and very short range forecast of cyclone "AILA" with radar data assimilation with rapid intermittent cycle using ARPS 3DVAR and cloud analysis techniques, Meteorol. Atmos. Phys., 124, 97-111, 2014.

Toon, O. B., Mckay, C. P., Ackerman, T. P., and Santhanam, K.: Rapid Calculation of Radiative Heating Rates and Photodissociation Rates in Inhomoge'neous Multiple-Scattering Atmospheres, J. Geophys. Res.-Atmos., 94, 16287-16301, 1989.

Wang, M., Xu, B. Q., Zhao, H. B., Cao, J. J., Joswiak, D., Wu, G. J., and Lin, S. B.: The Influence of Dust on Quantitative Measurements of Black Carbon in Ice and Snow when Using a Thermal Optical Method, Aerosol Sci. Tech., 46, 60-69, 2012.

Wang, P., Che, H. Z., Zhang, X. C., Song, Q. L., Wang, Y. Q., Zhang, Z. H., Dai, X., and Yu, D. J.: Aerosol optical properties of regional background atmosphere in Northeast China, Atmos. Environ., 44, 4404-4412, 2010.

Wang, X., Huang, J. P., Ji, M. X., and Higuchi, K.: Variability of East Asia dust events and their long-term trend, Atmos. Environ., 42, 3156-3165, 2008.

Wang, X., Huang, J. P., Zhang, R. D., Chen, B., and Bi, J. R.: Surface measurements of aerosol properties over northwest China during ARM China 2008 deployment, J. Geophys. Res.-Atmos., 115, D00k27, doi:10.1029/2009JD013467, 2010. 
Wang, X., Doherty, S. J., and Huang, J. P.: Black carbon and other light-absorbing impurities in snow across Northern China, J. Geophys. Res.-Atmos., 118, 1471-1492, 2013a.

Wang, X. G., Parrish, D., Kleist, D., and Whitaker, J.: GSI 3DVar-Based Ensemble-Variational Hybrid Data Assimilation for NCEP Global Forecast System: Single-Resolution Experiments, Mon. Weather. Rev., 141, 4098-4117, 2013 b.

Wang, X., Xu, B. Q., and Ming, J.: An Overview of the Studies on Black Carbon and Mineral Dust Deposition in Snow and Ice Cores in East Asia, J. Meteorol. Res.-Prc., 28, 354-370, 2014.

Wang, X., Pu, W., Zhang, X. Y., Ren, Y., and Huang, J. P.: Watersoluble ions and trace elements in surface snow and their potential source regions across northeastern China, Atmos. Environ., 114, 57-65, 2015.

Warren, S. G.: Optical-Properties of Snow, Rev. Geophys., 20, 6789, 1982.

Warren, S. G. and Wiscombe, W. J.: A Model for the Spectral Albedo of Snow .2. Snow Containing Atmospheric Aerosols, J. Atmos. Sci., 37, 2734-2745, 1980.

Warren, S. G. and Wiscombe, W. J.: Dirty Snow after Nuclear-War, Nature, 313, 467-470, 1985.

Wright, P., Bergin, M., Dibb, J., Lefer, B., Domine, F., Carman, T., Carmagnola, C., Dumont, M., Courville, Z., Schaaf, C., and Wang, Z. S.: Comparing MODIS daily snow albedo to spectral albedo field measurements in Central Greenland, Remote Sens. Environ., 140, 118-129, 2014.

Wuttke, S., Seckmeyer, G., Bernhard, G., Ehramjian, J., McKenzie, R., Johnston, P., and O'Neill, M.: New spectroradiometers complying with the NDSC standards, J. Atmos. Ocean. Tech., 23, 241-251, 2006a.

Wuttke, S., Seckmeyer, G., and König-Langlo, G.: Measurements of spectral snow albedo at Neumayer, Antarctica, Ann. Geophys., 24, 7-21, doi:10.5194/angeo-24-7-2006, 2006b.

Xia, X. A., Chen, H. B., Wang, P. C., Zong, X. M., Qiu, J. H., and Gouloub, P.: Aerosol properties and their spatial and temporal variations over North China in spring 2001, Tellus B, 57, 28-39, 2005.

Xia, X. G., Li, Z. Q., Holben, B., Wang, P., Eck, T., Chen, H. B., Cribb, M., and Zhao, Y. X.: Aerosol optical properties and radiative effects in the Yangtze Delta region of China, J. Geophys. Res.-Atmos., 112, D22s12, doi:10.1029/2007JD008859, 2007.

Xu, B. Q., Cao, J. J., Hansen, J., Yao, T. D., Joswia, D. R., Wang, N. L., Wu, G. J., Wang, M., Zhao, H. B., Yang, W., Liu, X. Q., and He, J. Q.: Black soot and the survival of Tibetan glaciers, P. Natl. Acad. Sci. USA, 106, 22114-22118, 2009.

Xu, B. Q., Cao, J. J., Joswiak, D. R., Liu, X. Q., Zhao, H. B., and He, J. Q.: Post-depositional enrichment of black soot in snowpack and accelerated melting of Tibetan glaciers, Environ. Res. Lett., 7, 014022, doi:10.1088/1748-9326/7/1/014022, 2012.

Yasunari, T. J., Bonasoni, P., Laj, P., Fujita, K., Vuillermoz, E., Marinoni, A., Cristofanelli, P., Duchi, R., Tartari, G., and Lau, K.-M.: Estimated impact of black carbon deposition during premonsoon season from Nepal Climate Observatory - Pyramid data and snow albedo changes over Himalayan glaciers, Atmos. Chem. Phys., 10, 6603-6615, doi:10.5194/acp-10-6603-2010, 2010.
Yasunari, T. J., Koster, R. D., Lau, W. K. M., and Kim, K. M.: Impact of snow darkening via dust, black carbon, and organic carbon on boreal spring climate in the Earth system, J. Geophys. Res.-Atmos., 120, 5485-5503, 2015.

Ye, H., Zhang, R. D., Shi, J. S., Huang, J. P., Warren, S. G., and $\mathrm{Fu}, \mathrm{Q}$.: Black carbon in seasonal snow across northern Xinjiang in northwestern China, Environ. Res. Lett., 7, 044002, doi:10.1088/1748-9326/7/4/044002, 2012.

Yesubabu, V., Srinivas, C. V., Hariprasad, K. B. R. R., and Baskaran, R.: A Study on the Impact of Observation Assimilation on the Numerical Simulation of Tropical Cyclones JAL and THANE Using 3DVAR, Pure Appl. Geophys., 171, 2023-2042, 2014.

Zawadzka, O., Makuch, P., Markowicz, K. M., Zielinski, T., Petelski, T., Ulevicius, V., Strzalkowska, A., Rozwadowska, A., and Gutowska, D.: Studies of aerosol optical depth with the use of Microtops II sun photometers and MODIS detectors in coastal areas of the Baltic Sea, Acta Geophys., 62, 400-422, 2014.

Zege, Ė. P., Ivanov, A. P., and Katsev, I. L.: Image transfer through a scattering medium, Springer Verlag, New York, 1991.

Zhang, R., Hegg, D. A., Huang, J., and Fu, Q.: Source attribution of insoluble light-absorbing particles in seasonal snow across northern China, Atmos. Chem. Phys., 13, 6091-6099, doi:10.5194/acp-13-6091-2013, 2013a.

Zhang, R., Jing, J., Tao, J., Hsu, S.-C., Wang, G., Cao, J., Lee, C. S. L., Zhu, L., Chen, Z., Zhao, Y., and Shen, Z.: Chemical characterization and source apportionment of $\mathrm{PM}_{2.5}$ in Beijing: seasonal perspective, Atmos. Chem. Phys., 13, 7053-7074, doi:10.5194/acp-13-7053-2013, 2013b.

Zhang, X. L., Wu, G. J., Kokhanovsky, A., Yao, T. D., and Tong D.: Spectral albedo parameterization for dirty snow with considering mirco-physicochemical properties of impurities - Part I: Theory and preliminary evaluation, in preparation, 2017.

Zhang, X. Y., Gong, S. L., Shen, Z. X., Mei, F. M., Xi, X. X., Liu, L. C., Zhou, Z. J., Wang, D., Wang, Y. Q., and Cheng, Y.: Characterization of soil dust aerosol in China and its transport and distribution during 2001 ACE-Asia: 1. Network observations, J. Geophys. Res.-Atmos., 108, 4261, doi:10.1029/2002JD002632, 2003.

Zhao, C., Hu, Z., Qian, Y., Ruby Leung, L., Huang, J., Huang, M., Jin, J., Flanner, M. G., Zhang, R., Wang, H., Yan, H., Lu, Z., and Streets, D. G.: Simulating black carbon and dust and their radiative forcing in seasonal snow: a case study over North China with field campaign measurements, Atmos. Chem. Phys., 14, 1147511491, doi:10.5194/acp-14-11475-2014, 2014. 